Alma Mater Studiorum - Università di Bologna DEPARTMENT OF ECONOMICS

\title{
Terrorism Risk and Democratic Preferences in Pakistan
}

Faiz Ur Rehman

Paolo Vanin

Quaderni - Working Paper DSE N 1037

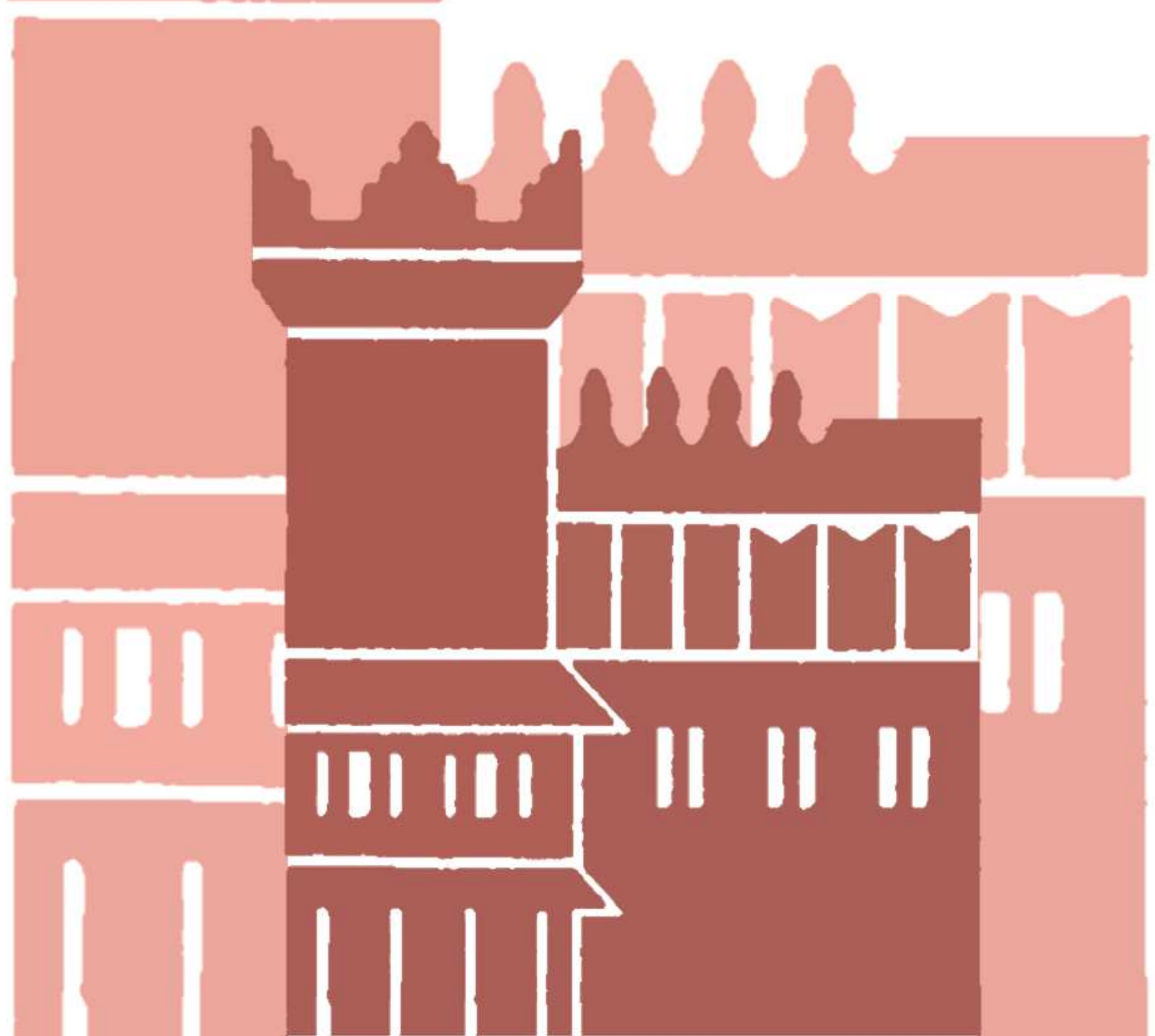




\title{
Terrorism Risk and Democratic Preferences in Pakistan*
}

\author{
Faiz Ur Rehman ${ }^{\dagger}$ \\ Paolo Vanin $\ddagger$
}

October 23, 2015

\begin{abstract}
Beyond direct damages, terrorism creates fear and insecurity, potentially reducing support for democratic institutions if these are deemed inadequate to tackle the threat, and increasing support for military governments. To investigate this possibility, we use data from Pakistan, a country that experienced an exponential rise in terrorism since 2001. Exploiting individual level data on democratic attitudes and district level information on terrorist attacks, we document that persistent exposure to terrorism (and more broadly to violence) is associated to a significantly lower support for democratic values. Results are robust to the inclusion of different sets of controls, to sample splits based on gender, urbanization and education, and to endogeneity considerations. Instrumenting terrorism and violence by the distance from the Pak-Afghan border and by religious fractionalization suggests that the documented correlation reflects a causal impact. Terrorism thus threatens not only individuals, but also democratic institutions.
\end{abstract}

Keywords: Terrorism, Institution, Democracy

JEL Classification: D74, F59, K42, O17

\footnotetext{
${ }^{*}$ The authors would like to thank Michael Faure, Diogo Gerhard, Muhammad Nasir, Jonathan Klick and Giovanni Prarolo, as well as participants to the Bologna Economics Department and Rotterdam Institute of Law \& Economics seminar series for their valuable comments. Similarly, we are grateful to Sustainable Development and Policy Institute (SDPI) and Pakistan Institute of Development Economics (PIDE) Islamabad for providing us an opportunity to present our work. All remaining mistakes are entirely our own.

${ }^{\dagger}$ Department of Economics, University of Bologna. Contact: faiz.rehman@edle-phd.eu

${ }^{\ddagger}$ Department of Economics, University of Bologna. Contact: paolo.vanin@unibo.it
} 


\section{Introduction}

Protecting individual life and property is among the most important responsibilities of states, and failure on this ground may lead to regime change. In the $21^{\text {st }}$ century, an escalation of terrorism and violent conflicts, often originating in developing countries but also with negative effects on advanced economies, threatens citizens' security in large parts of the world. We investigate the institutional legacy of violent conflicts and terrorism. In particular, we enquire whether terrorism, which typically aims at creating fear and insecurity, triggers or hinders democratic change. To this purpose, we exploit detailed information on democratic attitudes and on terrorism incidence in Pakistan.

Pakistan is one of the most terrorism-plagued countries in the world. ${ }^{1}$ Since its independence in 1947, a game of hide and seek prevails between democratic and military institutions to govern the country. Since 2008, it has an elected government, but it has oscillated between democracy and dictatorship with an approximately decade frequency. ${ }^{2}$ To fight terrorism, both under dictatorship and under democracy the government has relied more on the armed forces than on the police.

Our investigation is based on a micro-level survey conducted by Blair et al. (2013) on the model of the one run by the Freedom House (Freedom House, 2011). For 6,000 respondents, we relate the importance they attribute in 2009 to being governed by elected representatives and to the civilian control over the military, to the incidence of terrorism in their district of residence between 2004 and 2008 .

Our main finding is that persistent exposure to terrorism and violence decreases support for democratic values. A one-standard-deviation (one S.D.) increase in terrorist events reduces individual support for elected governments by $7-9 \%$. Similarly, it reduces support for civilian control over the military by $6-9 \%$. These results are robust to different empirical specifications, such as heterogeneous samples based on gender, urbanization and education level, as well as to the use of alternative measures of risk exposure. They are also robust to controlling for endogeneity, which might be an issue. On the one hand, endogeneity would reinforce our results if terrorists target

\footnotetext{
${ }^{1}$ The estimated direct costs of terrorism in Pakistan amount to US\$102.5 billion since the turn of the century (Economic Survey, 2013).

${ }^{2}$ The 2008 elections arrived after the Lawyer Movement, which in March 2007 protested against general Pervez Musharraf's dictatorship. Musharraf had unconstitutionally suspended the country's chief of justice Iftikhar Muhammad Chaudhry and he later imposed the emergency law and suspended the constitution. On November 3, 2007, the Supreme Court of Pakistan declared the state of emergency illegal and paved the way to the general elections.
} 
more frequently areas with higher support for democracy. On the other hand, our findings are ro-

bust to instrumenting terrorist attacks with the distance from the Pak-Afghan border (the Durand Line) and violence with religious fractionalization.

Our investigation is related to the economic literature on political transition, which has proposed different channels through which negative shocks might affect democracy and democratic preferences (Acemoglu and Robinson, 2001; Brückner and Ciccone, 2011; Ramsay, 2011). For instance, according to Acemoglu and Robinson (2001), bad economic conditions lower the opportunity cost of revolt, which incentivizes the state to provide rights in equilibrium. Our approach differs from Brückner and Ciccone (2011) and Ramsay (2011) on two main grounds: first, we focus on persistent exposure to terrorism rather than on transitory shocks; second, we investigate its effects on individual attitudes and preferences rather than on aggregate behavior.

Our study is also related to Voors et al. (2012) and Bellows and Miguel (2009), who, among others, find that individuals exposed to violence are more altruistic towards their neighbors, are more risk seeking, have higher discount rates, and are more likely to engage in political groups, vote in elections, attend community meetings and contribute to local social services. As it is far from clear how these effects on civic engagement and risk and time preferences translate into democratic attitudes, our findings can be seen in line with those of Blanco and Ruiz (2013) and Blanco (2012), who explore the negative impact of crime victimization and insecurity on satisfaction with democracy and on trust in institutions in Colombia and Mexico, respectively.

The rest of the paper is organized as follows. Section 2 expands on the related literature; Section 3 presents the data; the identification strategy is explained in Section 4; Section 5 presents the baseline empirical analysis; the transmission mechanism from terrorism risk to democratic attitudes is discussed in Section 6; Instrumental Variable (IV) results are reported in Section 7; and Section 8 concludes.

\section{Terrorism, Violence and Individual Preferences}

The literature on political economy discovers both optimistic and pessimistic results while exploring the impact of civil wars, violence, conflict, organized crimes and terrorism on institutional and democratic developments. It has tested the following hypotheses in different times and places: 
what is the democratic and institutional legacy of violence and conflict? Can perpetrators and victims become productive citizens once violence is over? In this section, we limit our focus to the exogenous impact (if any) of civil war, violent conflicts and terrorism on social and political institutions including social capital, norms, democratic values and political participation.

To start with the optimistic view, psychologists analyzed that victims of civil war and violent conflicts are resilient in general. They studied that victims of violence experience more personal growth than distress (Tedeschi and Calhoun, 2004); greater collective action (Wood, 2003); greater awareness and political participation (Bellows and Miguel, 2006, 2009) as the aftermath of a violent trauma.

Similarly, the political economy literature shows that violent conflicts and civil wars lead to the development of democratic institutions. For example, Cramer (2006) reports that violence can "produce institutional changes, amendments to the rules of the game. In retrospect, many changes that come to be seen as progressive have their origins in social conflicts that have taken a violent turn. Herein lies a paradox of violence and war: violence destroys but is also often associated with social creativity." Following these arguments, Blattman (2009) argues that past abductions of citizens by rebels in northern Uganda have led to increased political engagement of victims. Similarly, Bellows and Miguel (2009) find a positive correlation between conflict and socio-political behavior in Sierra Leone. In line with this literature, Bateson (2012) collects evidence from five continents which shows that individuals who are recently victimized, participate more in politics as compared to nonvictims. They become more engaged in political and civic life.

The optimistic view is further explored by political economists to analyze the correlation between violent conflicts and social capital. The relationship between conflict and social capital can be bi-directional. At one hand, asymmetric violence and terror increase tension, decrease cooperation, collective actions and trust (Colletta and Cullen, 2000). Studying comparative case studies, Colletta and Cullen (2000) found that violence weaken the social fabric, and wreck the social capital of a community, undermine interpersonal trust and collective action, divide community members, destroy values and norms, and if not solved, can lead to more communal conflict. However, on the other hand, individuals living under violent events are uncertain about their lives and economic opportunities, therefore, social interactions and capital might be formed on the solidarity basis to face a common external threat. 
In line with the optimistic results, a significant number of studies have explored that violent conflicts and civil wars improve social capital, instead of destroying it. It is observed that few African countries have witnessed a rapid post-war recovery which was not predicted by the Solow growth models. Social scientists have attributed this surge in growth to a change in social capital generated by violence itself. Analogous to this literature, Voors et al. (2012) study "that conflict affects preferences: individuals exposed to violence display more altruistic behavior towards their neighbors, are more risk seeking, and have higher discount rates." Similarly, Bellows and Miguel (2009) show that individuals who exposed to violence in Sierra Leone were more likely to participate in political groups and social community; vote in local elections, attend community meetings and contribute to local public goods. Also, Gilligan et al. (2010) find that individuals who were exposed to violence and conflict during Nepal's war are more likely to exhibit higher levels of social capital.

Nevertheless, significant number of studies have also discovered pessimistic results. They include the 2003 World Bank report (World Bank, 2003: 32) that claims "[t]he legacy effects of civil war are usually so adverse that they cannot reasonably be viewed as social progress....[Civil war] has been development in reverse" (Collier and Others, 2003). Similarly, terrorism, violence, conflict and civil wars are typically linked to the destruction of physical infrastructure and temporary drops in income. It has been studied, for example, by Davis and Weinstein (2002), Brakman et al. (2004) and Miguel and Roland (2011) for the economies of Japan, Germany and Vietnam, respectively. If one agrees with the above inferences, then the rebuilding of society after violent conflicts and terrorism may be more challenging and unlikely, and can contribute to the well known 'conflict trap' (Collier, 2007).

It is a well established fact that terrorism and violent conflicts adversely affect physical capital which drops incomes temporarily according to a simple Solow-style growth model. Nevertheless, researchers ignore their effects on institutional development, social norms, social capital, social organizations and preferences, while studying the income effect of a conflict. If asymmetric terrorism and warfare destroy physical capital and also lead to the erosion of social capital, social and cultural institutions, political and democratic processes, raise the level of impatience, then adverse level and growth effects can eventuate. The opposite can happen if exposure to violence invites institutional improvement including democratic processes.

Analogously, there are some studies which analyze negative associations between violent conflicts 
and electoral participation. For example, Bratton (2008) shows that violence negatively affects electoral participation in Nigeria, and that the most significant effect on turnout is the "experience of the threat of violence." Similarly, Collier and Vicente (2014) argue that voter intimidation in violent circumstances is effective in reducing voter turnout. In line with these results, Pinchotti and Verwimp (2007) has analyzed that exposure to conflict decrease perceptions of fairness and trust within communities in the post-war Tajikistan. Nevertheless, the literature on the correlation and causation between asymmetric warfare and social capital is new and not matured yet.

Asymmetric warfare, like violent conflicts, terrorism and civil wars, will probably have significant effects on both individual and community level preferences, behavior and social capital. Individual exposure to conflict is different from the community and his level of democratic preferences are likely to change relative to preferences within a community.

\section{Data}

We have utilized multiple data sources to collect information on variables of interest to us, i.e., (i) individuals' opinions/preferences on democratic values; (ii) the number of terrorist incidents at the district level; (iii) individual and district level measures of income, wealth and inequality; and (iv) individual and district level geographic and socio-religious characteristics. Tables 1-3 provide summary statistics of all relevant variables used in the following analysis.

\subsection{The Survey}

We derive individuals preferences on democratic and institutional features from a micro-level survey conducted by Blair et al. (2013) in collaboration with the Pakistani non-governmental organization, Socio-Economic Development Consultants (SEDCO). Blair et al. (2013) have fielded a 6,000households national level survey to measure individual level socio-economic, political and religious attitudes. They used the sample framework designed by the Federal Bureau of Statistics (FBS) Pakistan to draw a stratified random sample of adult Pakistani men and women. Similarly, they chose randomized sample from the four main provinces of the country: Punjab, Sindh, Khyber Pakhtunkhwa (KPK) and Baluchistan. Following the rural/urban breakdown in Pakistan's census, they randomly selected respondents within 500 primary sampling units (PSU): 332 in rural and 168 
in urban areas. The data is oversampled in the smaller provinces (Baluchistan and KPK) to ensure the collection of sufficient information in these sparsely populated and less developed provinces. Post-stratification survey weights were calculated which are derived from the last population census. A face-to-face questionnaire was fielded by six mixed-gender teams between April 21 and May 25, 2009. Males surveyed males and females surveyed females, consistent with the Pakistan's cultural values and norms to facilitate the interviewees. We derive our dependent variable from this survey which is discussed below.

\subsubsection{Democratic Attitudes}

It is a challenging task to measure people's opinion on civil liberties, human rights, institutional and democratic values in risky areas. ${ }^{3}$ However, Blair et al. (2013) tried to measure these opinions at the individual level in Pakistan, which is under the spiral of terrorism since the 1980s. They followed Freedom in the World (FIW) (Freedom House, 2011), that uses different institutional features to measure the extent of liberal democratic values. Blair et al. (2013) selected six institutional characteristics from the FIW survey while using questions to measure their support in Pakistan. The survey focuses on the specific institutional qualities of liberal democratic values. These include: governance by elected representatives, the freedom of assembly, free speech, civilian control over the military, property rights and independent courts. This study considers two values of a liberal democracy, given their importance in the democratic struggle of Pakistan. These are 'governance by elected representatives and civilian control over military.' The public opinion on the above two democratic values is represented by the following questions: i) how important is it for you to live in a country that is governed by representatives elected by the people? and ii) the 1973 Constitution of Pakistan says civilians should control the military. This means the military cannot take action without orders from civilian leaders. In your opinion, how much control should civilians have over the military.

To minimize between-subject variation due to respondent-specific beliefs about the democratic situation, the survey focuses on the specific institutional characteristics rather than on behavioral outcomes (i.e., perceptions about the legitimate action of the country) (Fair et al., 2013).

\footnotetext{
${ }^{3}$ Responses can be expressive in the survey data. Hillman (2010) notes that "response in a survey is a low-cost action that allows people to obtain expressive utility from the answer that they give, without consequences for any actions they need to undertake."
} 
Since the Lawyer Movement in March, 2007, which resulted in the restoration of democracy in Pakistan in February, 2008, democratic norms have gained currency in the Pakistani political economy discourse. At the same time, this debate has also included the critical analysis of government policies against continuous terrorism, which raised few questions on the deterrence level of democracy against terrorism in Pakistan.

This study explores the relationship between exposure to terrorism and the preferences for liberal democratic values, that is, 'governance by elected representatives' and 'civilian control over military.' The former institutional characteristic is measured on a five-point scale (extremely important, very important, moderately important, slightly important and not important at all), while the latter is measured on a different five-point scale (complete control, a lot of control, a moderate amount of control, a little control and no control at all). Respondents were asked to select one option from the five categories for each question. As shown in figures 1 and 2 , about $50 \%$ of the households selected the first two options for the 'elected representatives' and about $31 \%$ for the 'civilian control' values . Accordingly, we construct a dummy variable of two categories: the respondents who select the first two options is equal to ' 1 ' otherwise ' 0 '. Table 1 shows the distribution of preferences by respondents for the two proxies of democratic values.

Some scholars criticized the use of specific feature of democratic institutions as measure of democratic development. In this context, Blair et al. (2013) have mentioned limitations of their institutional measure. Similarly, Munck and Verkuilen (2002) noted the challenges in the measurement and definition of 'democratic values.' Nevertheless, given these complexities, Blair et al. (2013) study those institutional characteristics that are considered as the requisite parts of democracy, formulated by the international organizations like Freedom House. 
Table 1: Summary Statistics of Democratic Preferences (2009)

\begin{tabular}{lcccc}
\hline \hline Variable & Mean & Std. Dev. & Min & Max \\
\hline \multicolumn{5}{c}{ Original Measure } \\
\hline Elected Representatives & 1.90 & 1.01 & 1 & 5 \\
Civilian Control over Military & 3.20 & 1.35 & 1 & 5 \\
\hline \multicolumn{5}{c}{ Dummy Measure } \\
\hline Elected Representatives & 0.75 & 0.43 & 0 & 1 \\
Civilian Control over Military & 0.31 & 0.46 & 0 & 1 \\
\hline \hline
\end{tabular}

Note: The original measure for the 'elected representatives' is designed as: $1=$ extremely important, $2=$ very important, $3=$ moderately important, $4=$ slightly important and $5=$ not important at all. And for the "civilian control over military' is formulated as: 1 -complete control, $2=\mathrm{a}$ lot of control, $3=\mathrm{a}$ moderate amount of control, $4=$ a little control and $5=$ no control at all.

Dummy measure is equal to ' 1 ' if individual preferences are either 1 or 2 , otherwise ' 0 ' for both proxies.

Figure 1: Preferences for the Elected Representatives

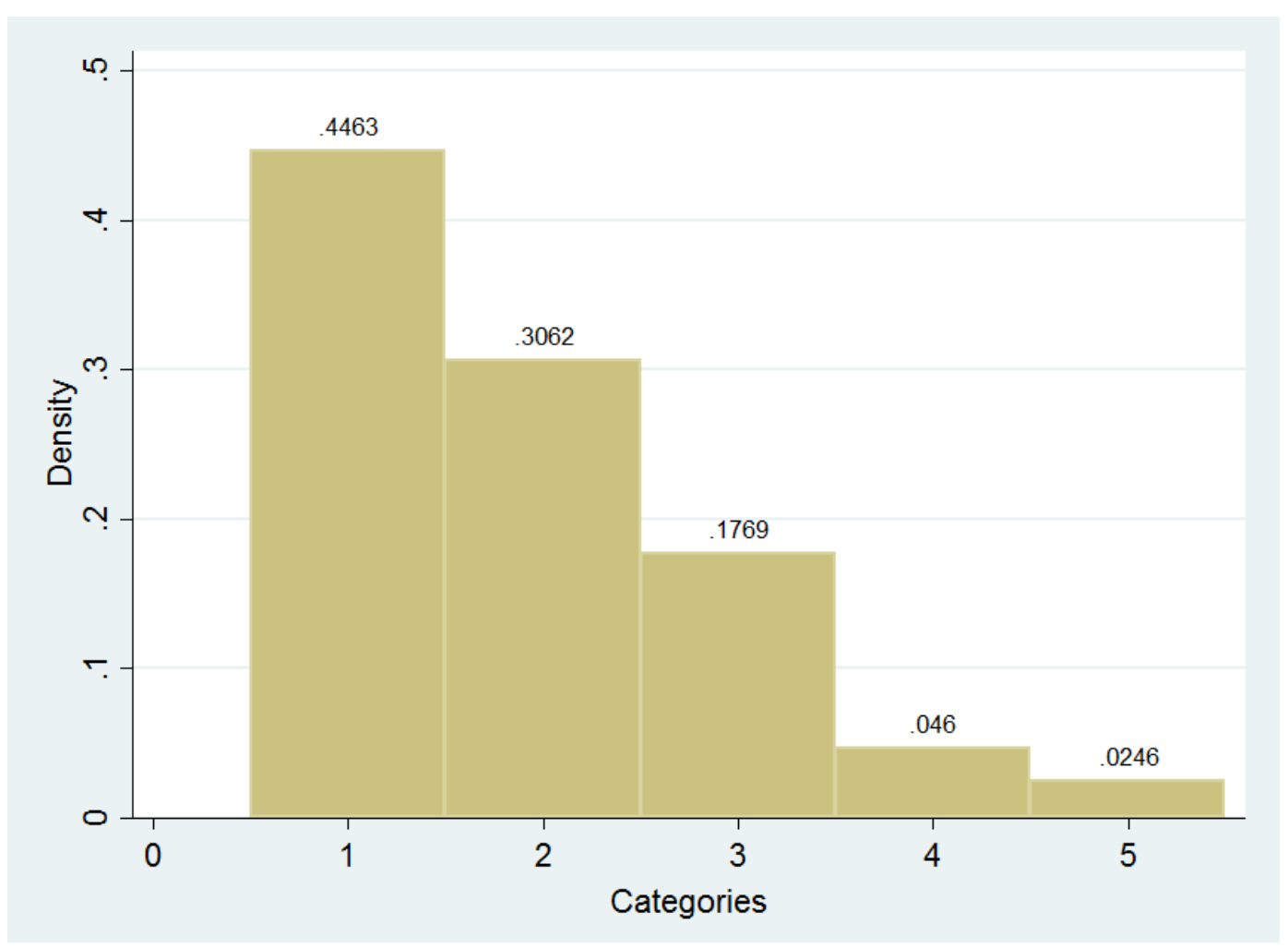


Figure 2: Preferences for the Civilian Control over Military Institution

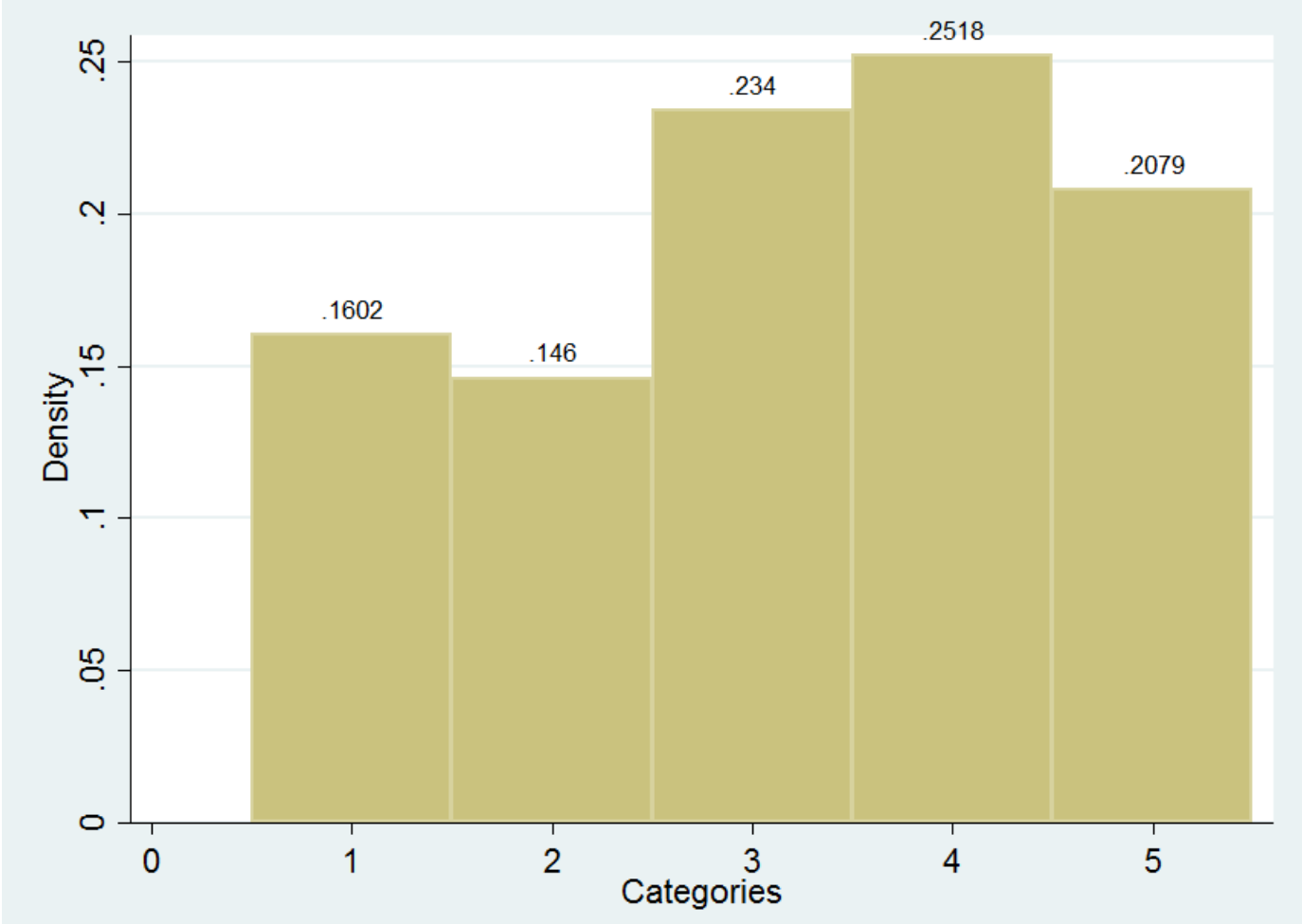

\subsection{Terrorism and Violence}

The most important control variable of our study is the number of district level terrorist attacks in Pakistan. The Global Terrorism Database (GTD) defines terrorism as, "a terrorist attack which fulfills the following three criterion: i) The incident must be intentional; ii) The incident must entail some level of violence or threat of violence and iii) The perpetrators of the incidents must be sub-national actors. In addition, at least two of the following three criterion must be present for an incident to be included in the GTD: i) The act must be aimed at attaining a political, economic, religious or social goal; ii) There must be evidence of an intention to coerce, intimidate or convey some other message to a larger audience (or audiences) than the immediate victims and iii) The action must be outside the context of legitimate warfare activities." As mentioned in the above definition, one of the main objectives of a terrorist organization is to coerce and intimidate a larger audience than the immediate victims. Hence, a terrorist incidence could also affect the political and economic attitudes and preferences of the larger audience than the immediate victims. Table 2 reports descriptive statistics of total number of terrorist events and acts of different kinds of 
violent conflicts (violence) ${ }^{4}$ between 2004-2008 ${ }^{5}$, while figures 3-6 visualize district level terrorist attacks and violence over time and space, respectively. We use different kinds of violence events as an alternative indicator of 'exposure to risk' and analyze its impact on the public opinion about democratic norms. The correlation between terrorism and violence is 0.70 , which can be observed from figures 5 and 6. Although terrorism in Pakistan is not a new phenomenon, but the marginal change in terrorist attacks is positive and increasing since 2004-2005 (see figure 3). The increasing number of terrorism and violence since 2004-2005 demands attention to explore their impact on individual preferences toward democratic norms.

Figure 3: Monthly Terrorist Attacks (2001-2012)

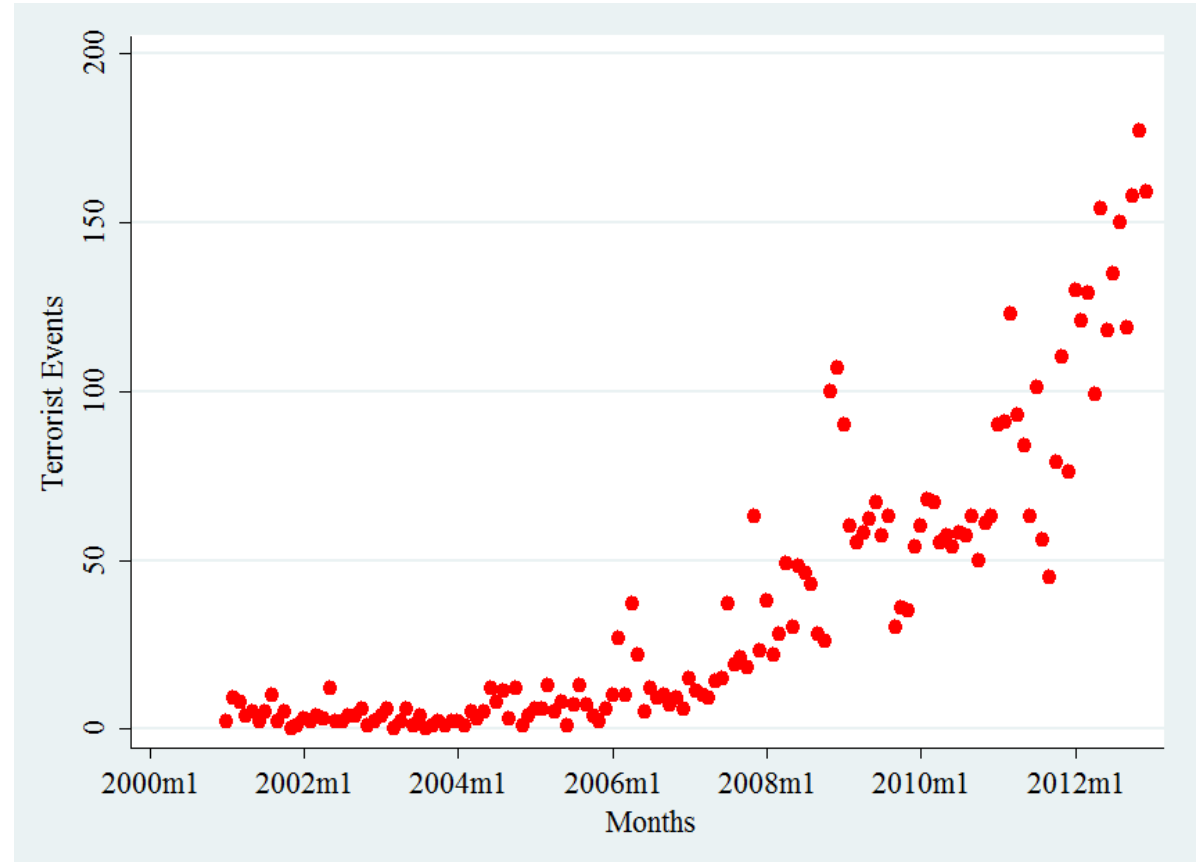

\footnotetext{
${ }^{4}$ Violence include assassination, extortion, target killings, violent political demonstrations, communal, sectarian and ethnic clashes.

${ }^{5}$ Although, we have district level terror attacks from 2001-2012, we use terrorist attacks only from the period 2004-2008, because there has been a surge in terrorism in Pakistan since 2004. We also tested our baseline results for the terrorist attacks from 2001-2008, however, the results do not change. These results are available on reader's request.
} 
Figure 4: Monthly Violence Incidents (2001-2011)

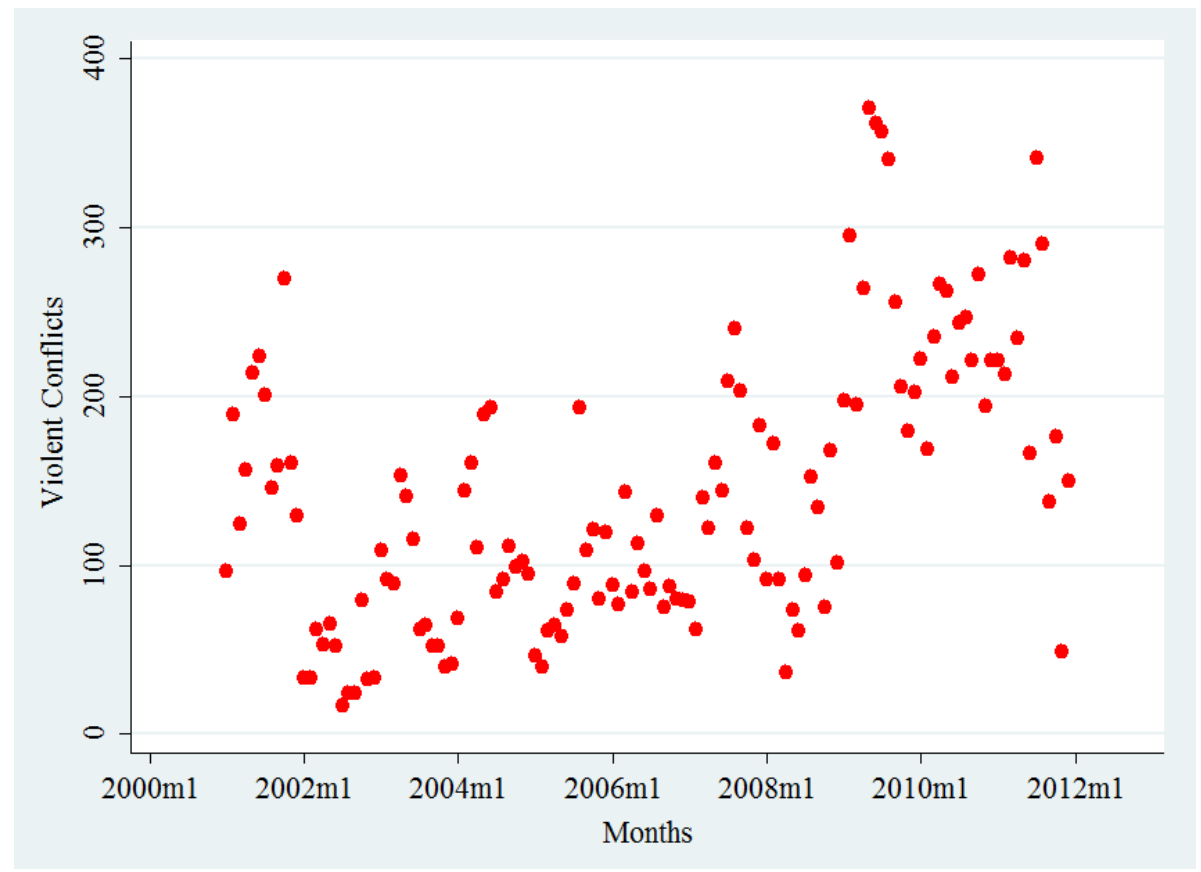

Figure 5: Geographic Distribution of Terrorist Attacks (2004-2008). Bigger the Circle, Higher the Terrorist Attacks.

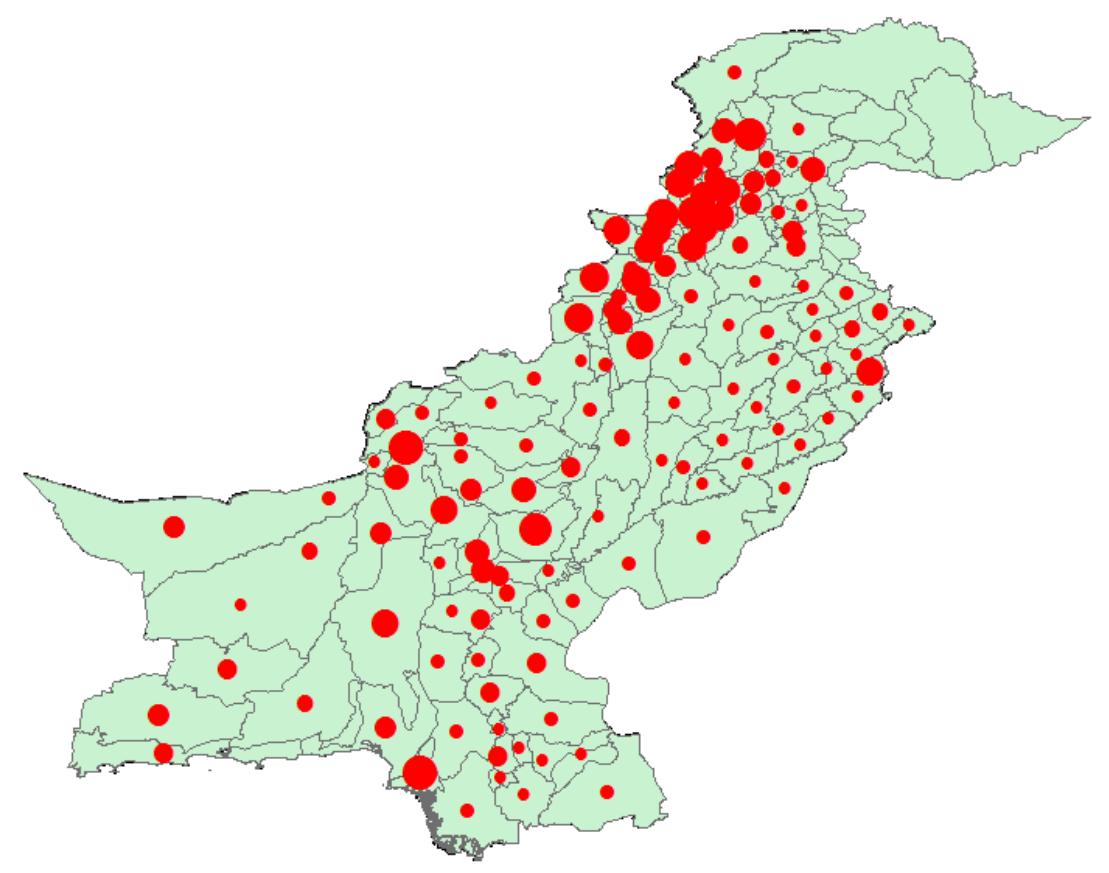


Figure 6: Geographic Distribution of Violence Incidents (2004-2008). Bigger the Circle, Higher the Violence.

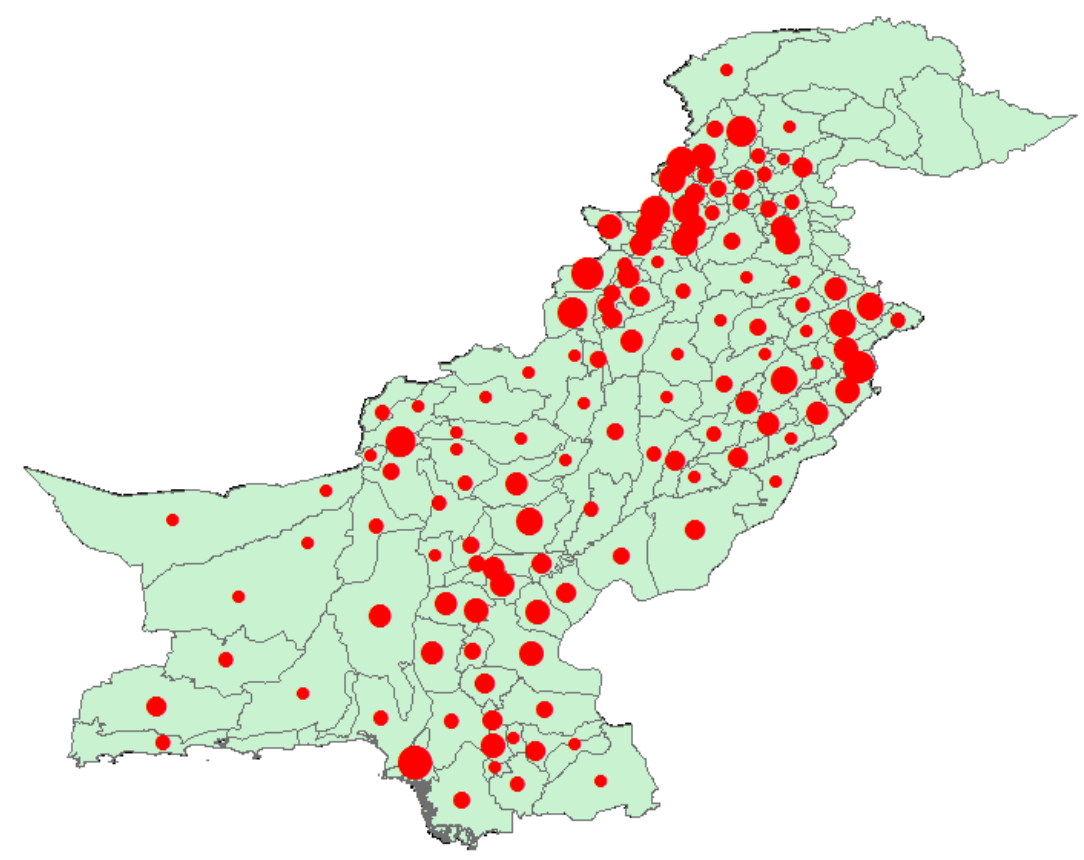

Table 2: Summary Statistics of District Level Terrorist Attacks and Violence Incidents (2004-2008)

\begin{tabular}{lcccc}
\hline \hline Variable & Mean & Std. Dev. & Min & Max \\
\hline Terrorism & 52.004 & 82.04 & 1 & 365 \\
$\log$ (Terrorism) & 2.87 & 1.53 & 0 & 5.90 \\
Violence & 246.87 & 367.20 & 1 & 1278 \\
$\log ($ Violence) & 4.61 & 1.41 & 0 & 7.15 \\
\hline \hline Source: De Mesquita et al. (2013) and Global Terrorism
\end{tabular}

Source: De Mesquita et al. (2013) and Global Terrorism Database (2013).

\subsection{Control Variables}

Other control variables include demographic, socio-economic and religious characteristics. Demographic controls are rural/urban belonging, gender, age, language, education level, marital status, population density and share of urban population. Socio-economic characteristics include nominal income at individual and district level, profession, individual level economic opinions about relative income overtime and space, inequality and land reforms. The additive asset index is calculated from the possession of the following assets at individual level: television, air conditioner, street lamps, home outdoor area, computer, cell phone, car, newspaper and internet. Socio-economic 
controls also include multiple deprivation index which is constructed from district level education, health and housing variables. Lastly, religious controls include sect type, religious fractionalization, recitation of the holy book, frequency of recitation and role of the Sharia law in the current legal framework. Table 3 presents the descriptive statistics of other control variables.

\section{Empirical Strategy}

This section presents the econometric strategy to explore the effect of terrorism and violence on support for democratic values. As discussed above, we use individual perception and preferences about specific institutional features as a proxy for democratic values. To get the individual preferences, we rely on a micro level survey of 6,000 respondents. The number of terrorist attacks and violent incidents are time-variant but the survey is time-invariant, which constraint us to rely only on the cross-sectional dimension. We argue that district level terrorist attacks are exogenous to individual level political preferences, thus, the probability of reverse causality is low. ${ }^{6}$ Similarly, we separate samples on the basis of gender, urbanization and education level to assess heterogeneous responses to terrorism. Nonetheless, we include socio-economic and religious controls to our baseline regressions in order to minimize the extent of reverse causality, measurement errors and omitted variable biases. As a robustness test, results based on Instrumental Variable identification strategy are reported in section 7 .

Our baseline estimating probit equation is:

$$
P_{i d} \equiv \operatorname{Pr}\left(y_{i d}=1 \mid X, Z\right)=\beta \text { terrorism }{ }_{d}+\gamma^{\prime} X_{i}+\delta^{\prime} Z_{d}+\phi_{p}+\epsilon_{i}
$$

where

$$
y_{i d}= \begin{cases}1 & \text { with probability } P \text { if an individual } i \text { supports democratic values in district } d \\ 0 & \text { with probability } 1-P \text { otherwise }\end{cases}
$$

$y_{i d}$ are the preferences of individual $i$ on democratic values in 2009 in district $d$; terrorism is the indicator for district level terrorist attacks as discussed above; $X_{i}$ is a set of individual control

\footnotetext{
${ }^{6}$ For example, in figure 5, the terrorist attacks are random except the North-West part along the Durand Line. However, the survey did not include respondents from that part due to security risk.
} 
Table 3: Summary Statistics of Demographic, Social, Economic and Religious Controls

\begin{tabular}{|c|c|c|c|c|}
\hline Variable(s) & Mean & Std. Dev. & Min & Max \\
\hline \multicolumn{5}{|c|}{ Individual Level Demographic, Social, Economic and Religious Controls } \\
\hline Urban & 0.34 & 0.47 & 0 & 1 \\
\hline Female & 0.48 & 0.50 & 0 & 1 \\
\hline Language & 2.85 & 1.48 & 1 & 7 \\
\hline Pushto Language & 0.16 & 0.37 & 0 & 1 \\
\hline Age & 33.50 & 11.35 & 18 & 88 \\
\hline Age Squared & 1251.48 & 895.64 & 324 & 7744 \\
\hline Marital Status & 0.77 & 0.42 & 0 & 1 \\
\hline Education (all categories) & 4.22 & 2.23 & 1 & 7 \\
\hline Primary & 0.13 & 0.33 & 0 & 1 \\
\hline Middle & 0.14 & 0.35 & 0 & 1 \\
\hline Matric & 0.19 & 0.39 & 0 & 1 \\
\hline Intermediate & 0.13 & 0.33 & 0 & 1 \\
\hline Graduate & 0.06 & 0.25 & 0 & 1 \\
\hline Professionals & 0.02 & 0.14 & 0 & 1 \\
\hline Illiterate & 0.33 & 0.47 & 0 & 1 \\
\hline Occupation & 4.11 & 1.97 & 1 & 11 \\
\hline Nominal Income & 9.64 & 6.85 & 0.10 & 100 \\
\hline Asset Index & 0.43 & 0.19 & 0 & 1 \\
\hline Earn Less & 0.36 & 0.48 & 0 & 1 \\
\hline Earn More & 0.18 & 0.39 & 0 & 1 \\
\hline Better Financial Situation & 0.30 & 0.46 & 0 & 1 \\
\hline Worse Financial situation & 0.50 & 0.50 & 0 & 1 \\
\hline Land Reforms & 0.40 & 0.49 & 0 & 1 \\
\hline Inequality & 0.54 & 0.50 & 0 & 1 \\
\hline Sunni & 0.96 & 0.18 & 0 & 1 \\
\hline Recitation of the Holy Book & 0.57 & 0.50 & 0 & 1 \\
\hline Frequency of Recitation & 0.20 & 0.40 & 0 & 1 \\
\hline Role of Sharia Law & 0.73 & 0.26 & 0 & 1 \\
\hline \multicolumn{5}{|c|}{ District Level Demographic, Social, Economic and Religious Controls } \\
\hline Multiple Deprivation Index (MDI) & 32.89 & 14.04 & 12.77 & 75.29 \\
\hline Population Density & 2161.52 & 5878.87 & 20.64 & 33014 \\
\hline Urbanization Rate & 38.28 & 26.29 & 5.3 & 100 \\
\hline \multicolumn{5}{|c|}{ Instrumental Variable(s) } \\
\hline Distance from the Durand Line & 460.92 & 208.48 & 137.38 & 912.25 \\
\hline Herfindahl-Hirschman Index (HHI) & 0.50 & 0.17 & 0.25 & 0.92 \\
\hline
\end{tabular}

Note: Nominal income is in rupees which is standardized by dividing on 1000; asset index is an additive index of assets like TV, air conditioning, cell phone, car, outdoor area, etc.; earn less and earn more are economic opinions compare to past period; better financial and worse financial situations are economic opinions compare to neighbors. HHI is a district level index of religious fractionalization. 
variables; $Z_{d}$ is a set of district level controls; $\phi_{p}$ are province-fixed effects and finally $\epsilon_{i}$ is an error term. The set of observable $X_{i}$ and $Z_{d}$ comprises of demographic, religious and socio-economic determinants of individual preferences on democracy.

\section{Democratic Attitudes and Terrorism}

\subsection{Baseline Evidence}

Regression estimates on equation (1) are reported in table $4 .{ }^{7}$ At first, we estimate the raw correlation between the dummy measures of democratic values and the number of terrorist events, then we progressively add the set of control variables to our baseline specification. The first two panels of the table 4 show that the number of terrorist attacks is significantly associated to lower support for elected governments and for civilian control over the military, respectively. Such result is robust across specifications both in significance and in magnitude. A one S.D. increase in exposure to terrorism significantly reduces both support for democratic governments and for civilian control over the military by $6-8 \%$, depending on the specification.

Our main result supports the pessimistic argument that exposure to terrorist attacks weakens democratic values. Nonetheless, the following might be the reasons for this negative relationship. First of all, the survey was conducted in the regime of the 2009 democratic government, which had failed to supply public goods in sufficient quantity that could save lives and property of its citizens or helped to reduce future risk of terrorism. The results could be a natural response from the respondents to show their disapproval for democratic values, if the elected legislators were unable to protect their basic human rights. Secondly, the above argument is strengthened by the prevalent civil-military imbalance in Pakistan's political landscape. The military dictators were more successful than elected legislatures to transfer power at the local level, giving elected representation more weightage in conducting affairs than relying on inefficient bureaucratic administration. This gives an impression that democratic governments lack the will to decentralize resources and power from central structure to the micro level. ${ }^{8}$ Hence, the lackluster administrative performance

\footnotetext{
${ }^{7}$ Regression results with the estimated coefficients of control variables are available upon request.

${ }^{8}$ The Discretionary Development Fund (DDF) allocates resources in the annual budget for the parliamentarians. The basic purpose is to channel money from the central government directly to the electoral constituencies for local infrastructure projects. In Pakistan, each National and Provincial Assembly member receives US\$ 240,356 and 60,089, respectively (Tshangana, 2010). If power transfers at the municipality level, the municipality representative has to
} 
of democratic institutions at local level further adds to the failure of service delivery and loss of confidence in democracy by the people. Thirdly, Pakistan has a rich history of democratic struggle which started from her inception in 1947 till the Lawyer Movement in 2007; therefore, a specific dictator could not rule for more than a decade, giving way to mixed feelings by the populace for both substitutable regimes (democracy vs. dictatorship).

The possible explanation for the relationship between terrorism and civilian control over the military is that the army is often perceived as the only law enforcement agency which is effectively engaged against domestic terrorists since $9 / 11 .^{9}$ Therefore, people may react to terrorism by considering an independent army the best safeguard of their lives and property.

Table 4: Terrorism and Democratic Values

\begin{tabular}{lcccccc}
\hline \hline & $(1)$ & $(2)$ & $(3)$ & $(4)$ & $(5)$ & $(6)$ \\
\hline \multicolumn{7}{c}{ Preferences on Elected Representatives } \\
\hline Terrorism (log) & $-0.169^{* * *}$ & $-0.123^{* * *}$ & $-0.148^{* * *}$ & $-0.143^{* * *}$ & $-0.144^{* * *}$ & $-0.138^{* * *}$ \\
& {$[0.0117]$} & {$[0.0169]$} & {$[0.0225]$} & {$[0.0229]$} & {$[0.0235]$} & {$[0.0241]$} \\
Marginal Effect & -0.05 & -0.04 & -0.05 & -0.04 & -0.04 & -0.04 \\
One S.D. Effect & -0.08 & -0.06 & -0.08 & -0.06 & -0.06 & -0.06 \\
Pseudo R-Square & 0.03 & 0.10 & 0.10 & 0.11 & 0.11 & 0.17 \\
\hline & \multicolumn{7}{c}{ Preferences on Civilian Control over Military } \\
\hline Terrorism (log) & $-0.125^{* * *}$ & $-0.203^{* * *}$ & $-0.166^{* * *}$ & $-0.151^{* * *}$ & $-0.146^{* * *}$ & $-0.143^{* * *}$ \\
& {$[0.0126]$} & {$[0.0180]$} & {$[0.0281]$} & {$[0.0285]$} & {$[0.0293]$} & {$[0.0296]$} \\
Marginal Effect & -0.04 & -0.05 & -0.04 & -0.04 & -0.04 & -0.04 \\
One S.D. Effect & -0.06 & -0.08 & -0.06 & -0.06 & -0.06 & -0.06 \\
Pseudo R-Square & 0.02 & 0.08 & 0.10 & 0.11 & 0.11 & 0.13 \\
\hline Province Fixed Effects & $\mathrm{N}$ & $\mathrm{Y}$ & $\mathrm{Y}$ & $\mathrm{Y}$ & $\mathrm{Y}$ & $\mathrm{Y}$ \\
Demographic Controls & $\mathrm{N}$ & $\mathrm{N}$ & $\mathrm{Y}$ & $\mathrm{Y}$ & $\mathrm{Y}$ & $\mathrm{Y}$ \\
Economic Controls & $\mathrm{N}$ & $\mathrm{N}$ & $\mathrm{N}$ & $\mathrm{Y}$ & $\mathrm{Y}$ & $\mathrm{Y}$ \\
Language Controls & $\mathrm{N}$ & $\mathrm{N}$ & $\mathrm{N}$ & $\mathrm{N}$ & $\mathrm{Y}$ & $\mathrm{Y}$ \\
Religious Controls & $\mathrm{N}$ & $\mathrm{N}$ & $\mathrm{N}$ & $\mathrm{N}$ & $\mathrm{N}$ & $\mathrm{Y}$ \\
\hline \hline
\end{tabular}

Note: Dependent variable is a dummy which captures individual political attitudes for liberal democratic values. Probit regressions predicting preferences for institutional norms (govern by elected representatives $(\mathrm{N}=5891)$ \& civilian control over military $(\mathrm{N}=5770)$ ). Demographic controls include gender, marital status, rural/urban, age, age-square and formal education level. Economic controls include nominal income, occupation, assets, multiple deprivation index, perceptions on land reforms, inequality, future financial expectations and financial comparison with the neighborhood. Language controls for five main languages speak across Pakistan. Religious controls include sect type, number of prayers, recitation of the holy book, frequency of recitation and current role of the Sharia's law. Robust standard errors (clustered at district level) are presented in brackets.

$* * * p<0.01, * * p<0.05$ and $* p<0.10$.

spend resources on the local development projects. Parliamentarians can no longer exploit these resources. Due to the rent-seeking opportunity, democratic government does not want to transfer power at the local level (ICG, 2013).

${ }^{9}$ According to a report submitted to the Supreme Court of Pakistan by top spy agencies about the total number of casualties caused by terrorist attacks since 9/11, the armed forces have suffered 15,681 casualties while fighting domestic terrorists in the tribal areas since 2008, with 2009 being the deadliest year for them. http://tribune.com.pk/story/527016/pakistani-victims-war-on-terror-toll-put-at-49000/ 


\subsection{Democratic Attitudes and Violence}

In this section, we use violent conflicts (violence) as an alternative indicator of exposure to risk, which we believe, might affect the political opinion of an ordinary citizen. The intuition is that violence may impose negative externalities at the local rather than the national level, due to mass media coverage of terrorism than violence.

Religious, ethnic and nationalistic violence has escalated in Pakistan since 1980s, which is continuing till to date. We assume that consistent and long-term conflicts also create negative sanctions and externalities on the life and property of a common individual just like terrorism. Consequently, we argue that violence can change the risk preferences of an individual towards his expected life and property, which in turn may determine his democratic perceptions.

We measure violence as an aggregation of sectarian, ethnic and nationalistic conflicts. The correlation between violence and terrorism is 0.70 . The results obtained while using violence as a main regressor are presented in table 5. The sign and statistical significance of the estimated coefficients for the violence regressor are similar with the base line specifications of terrorism in table 4. Except for specification (1), the effect of a one S.D. increase in violence on preferences for elected legislators are about the same with those observed in table 4.

Similarly, the parameter estimates in table 5 are also consistent with our baseline estimates when we consider the correlation between violence and civilian control over the military. Although, estimated coefficients of violence have lower absolutes values, nevertheless, they are robust in sign and significance.

\subsection{Sensitivity Check}

While exposure to terrorism is likely to affect preferences, nevertheless, current terrorism incidents are more likely to shape democratic attitudes than the lag attacks. To capture the memory effect of terrorist risk on political attitudes, we analyze the response of individuals to terrorist attacks between January-May, 2009. The reason is that the survey is conducted around this time interval from which we derive our proxies of democratic preferences. The regression results based on terrorism between January-May, 2009 are reported in table 6 .

The estimated parameters of current exposure to terrorism on support for elected governments 
Table 5: Violence and Democratic Values

\begin{tabular}{lcccccc}
\hline \hline & $(1)$ & $(2)$ & $(3)$ & $(4)$ & $(5)$ & $(6)$ \\
\hline \multicolumn{7}{c}{ Preferences on Elected Representatives } \\
\hline Violence (log) & 0.012 & $-0.135^{* * *}$ & $-0.206^{* * *}$ & $-0.204^{* * *}$ & $-0.203^{* * *}$ & $-0.181^{* * *}$ \\
& {$[0.0126]$} & {$[0.0199]$} & {$[0.0302]$} & {$[0.0308]$} & {$[0.0325]$} & {$[0.0311]$} \\
Marginal Effect & 0.003 & -0.04 & -0.06 & -0.06 & -0.06 & -0.05 \\
One S.D. Effect & 0.004 & -0.06 & -0.08 & -0.08 & -0.08 & -0.07 \\
Pseudo R-Square & 0.0001 & 0.10 & 0.10 & 0.11 & 0.12 & 0.17 \\
\hline \multicolumn{7}{c}{ Preferences on Civilian Control over Military } \\
\hline Violence (log) & $-0.145^{* * *}$ & $-0.159^{* * *}$ & $-0.120^{* * *}$ & $-0.101^{* * *}$ & $-0.0975^{* * *}$ & $-0.104^{* * *}$ \\
& {$[0.0149]$} & {$[0.0200]$} & {$[0.0294]$} & {$[0.0298]$} & {$[0.0306]$} & {$[0.0302]$} \\
Marginal Effect & -0.04 & -0.04 & -0.03 & -0.03 & -0.03 & -0.03 \\
One S.D. Effect & -0.06 & -0.06 & -0.04 & -0.04 & -0.04 & -0.04 \\
Pseudo R-Square & 0.02 & 0.07 & 0.09 & 0.11 & 0.11 & 0.12 \\
\hline Province Fixed Effects & $\mathrm{N}$ & $\mathrm{Y}$ & $\mathrm{Y}$ & $\mathrm{Y}$ & $\mathrm{Y}$ & $\mathrm{Y}$ \\
Demographic Controls & $\mathrm{N}$ & $\mathrm{N}$ & $\mathrm{Y}$ & $\mathrm{Y}$ & $\mathrm{Y}$ & $\mathrm{Y}$ \\
Economic Controls & $\mathrm{N}$ & $\mathrm{N}$ & $\mathrm{N}$ & $\mathrm{Y}$ & $\mathrm{Y}$ & $\mathrm{Y}$ \\
Language Controls & $\mathrm{N}$ & $\mathrm{N}$ & $\mathrm{N}$ & $\mathrm{N}$ & $\mathrm{Y}$ & $\mathrm{Y}$ \\
Religious Controls & $\mathrm{N}$ & $\mathrm{N}$ & $\mathrm{N}$ & $\mathrm{N}$ & $\mathrm{N}$ & $\mathrm{Y}$ \\
\hline \hline
\end{tabular}

Note: Dependent variable is a dummy which captures individual political attitudes for liberal democratic values. Probit regressions predicting preferences for institutional norms (govern by elected representatives $(\mathrm{N}=5891)$ \& civilian control over military $(\mathrm{N}=5770)$ ). Demographic controls include gender, marital status, rural/urban, age, age-square and formal education level. Economic controls include nominal income, occupation, assets, multiple deprivation index, perceptions on land reforms, inequality, future financial expectations and financial comparison with the neighborhood. Language controls for five main languages speak across Pakistan. Religious controls include sect type, number of prayers, recitation of the holy book, frequency of recitation and current role of the Sharia's law. Robust standard errors (clustered at district level) are presented in brackets.

$* * * p<0.01, * * p<0.05$ and $* p<0.10$. 
and civilian control over the military are negative and statistically significant in all specifications, although the magnitude of the effect of current exposure to terrorism is lower than that of permanent exposure. This suggests that continuous terrorist attacks over the years cause people to adjust their attitude to the average level of terrorism per week/month. Due to the convergence of expectations to the mean value of terrorism, recent attacks may not significantly shift political values. Nevertheless, long-term and consistent exposure to terrorism risk alter individuals support for institutions which perceive to effectively deter terrorism.

Table 6: Terrorism (January-May, 2009) and Democratic Values

\begin{tabular}{|c|c|c|c|c|c|c|}
\hline & $(1)$ & $(2)$ & $(3)$ & $(4)$ & $(5)$ & $(6)$ \\
\hline \multicolumn{7}{|c|}{ Preferences on Elected Representatives } \\
\hline \multirow[t]{2}{*}{ Terrorism $(\log )$} & $-0.170^{* * *}$ & $-0.0856^{* * *}$ & $-0.0779^{* * *}$ & $-0.0667^{* * *}$ & $-0.0673^{* * *}$ & $-0.0599 * *$ \\
\hline & {$[0.0120]$} & {$[0.0195]$} & {$[0.0241]$} & {$[0.0245]$} & {$[0.0248]$} & {$[0.0252]$} \\
\hline Marginal Effect & -0.05 & -0.03 & -0.02 & -0.02 & -0.02 & -0.02 \\
\hline One S.D. Effect & -0.07 & -0.04 & -0.03 & -0.03 & -0.03 & -0.03 \\
\hline \multirow[t]{2}{*}{ Pseudo R-Square } & 0.03 & 0.09 & 0.09 & 0.11 & 0.11 & 0.17 \\
\hline & \multicolumn{5}{|c|}{ Preferences on Civilian Control over Military } & \\
\hline \multirow[t]{2}{*}{ Terrorism $(\log )$} & $-0.0552^{* * *}$ & $-0.194^{* * *}$ & $-0.0918^{* * *}$ & $-0.0765^{* *}$ & $-0.0617^{* *}$ & $-0.0622^{* *}$ \\
\hline & {$[0.0125]$} & {$[0.0211]$} & {$[0.0300]$} & {$[0.0308]$} & {$[0.0313]$} & {$[0.0316]$} \\
\hline Marginal Effect & -0.02 & -0.05 & -0.02 & -0.02 & -0.02 & -0.02 \\
\hline One S.D. Effect & -0.03 & -0.07 & -0.03 & -0.03 & -0.03 & -0.03 \\
\hline Pseudo R-Square & 0.003 & 0.07 & 0.09 & 0.10 & 0.11 & 0.12 \\
\hline Province Fixed Effects & $\mathrm{N}$ & $\mathrm{Y}$ & $\mathrm{Y}$ & $\mathrm{Y}$ & $\mathrm{Y}$ & $\mathrm{Y}$ \\
\hline Demographic Controls & $\mathrm{N}$ & $\mathrm{N}$ & $\mathrm{Y}$ & $\mathrm{Y}$ & $\mathrm{Y}$ & $\mathrm{Y}$ \\
\hline Economic Controls & $\mathrm{N}$ & $\mathrm{N}$ & $\mathrm{N}$ & $\mathrm{Y}$ & $\mathrm{Y}$ & $\mathrm{Y}$ \\
\hline Language Controls & $\mathrm{N}$ & $\mathrm{N}$ & $\mathrm{N}$ & $\mathrm{N}$ & $\mathrm{Y}$ & $\mathrm{Y}$ \\
\hline Religious Controls & $\mathrm{N}$ & $\mathrm{N}$ & $\mathrm{N}$ & $\mathrm{N}$ & $\mathrm{N}$ & $\mathrm{Y}$ \\
\hline
\end{tabular}

$\overline{\text { Note: Dependent variable is a dummy which captures individual political attitudes for liberal democratic values. Probit }}$ regressions predicting preferences for institutional norms (govern by elected representatives $(\mathrm{N}=5891)$ \& civilian control over military $(\mathrm{N}=5770)$ ). Demographic controls include gender, marital status, rural/urban, age, age-square and formal education level. Economic controls include nominal income, occupation, assets, multiple deprivation index, perceptions on land reforms, inequality, future financial expectations and financial comparison with the neighborhood. Language controls for five main languages speak across Pakistan. Religious controls include sect type, number of prayers, recitation of the holy book, frequency of recitation and current role of the Sharia's law. Robust standard errors (clustered at district level) are presented in brackets.

$* * * p<0.01, * * p<0.05$ and $* p<0.10$. 


\subsection{Heterogeneous Effects}

\subsubsection{Male Vs. Female}

In this section, we analyze the heterogeneous effects of terrorism risk on democratic attitudes, based on gender separated samples. The basic purpose is to compare disaggregated preferences with the aggregate estimates of table 4. Due to cultural and religious constraints on women in Pakistan, female labor force participation is significantly lower than male. In 2009, the female participation rate in the labor market was $24.1 \%$ as compared to $81.7 \%$ by their male counterpart (WDI, 2015). Similar sanctions also put constraints on the electoral turnout of women. ${ }^{10}$ Hence, it can be argued that males vis-à-vis females are more exposed to the threat of terrorism, which may lead to a negative political attitude towards democratic values. To test this heterogeneous effect on the basis of gender, the regression results are given in table 7 for both democratic proxies.

Compare to the base line estimates in table 4, the gender separated sample results for males relative to females are consistent in statistical significance and signs for both democratic proxies. The important information that we can get from male-female heterogeneous samples in table 7 is that the absolute value of a one S.D. effect of terrorism is significantly higher in magnitude for males vis-à-vis females.

\subsubsection{Urban Vs. Rural}

There exists significant heterogeneity between rural-urban proximity based on socio-economic and religious characteristics across Pakistan. For example, about $65 \%$ of the total population live in rural municipalities. Rural agriculture sector provides employment to about $43.7 \%$ of the total labor force (Economic Survey, 2013). Similarly, 45\% of the total terrorist attacks targeted districts with $100 \%$ urbanized municipalities. It may be argued that terrorists preferred targets are urban municipalities having higher population density and media coverage. Further, it can be argued that urban residents are more exposed to the risk of terrorism than rural inhabitants. Thus, it is intriguing to analyze separately their democratic attitudes amid terrorism risk.

Table 8 shows regression results based on urban-rural distribution of population. The esti-

\footnotetext{
${ }^{10}$ The Election Commission of Pakistan (ECP) did not disintegrate yet the electoral turnout on the basis of gender, however, media reports during the election days show that female participation is generally lower then the male (Freedom House, 2014).
} 
Table 7: Terrorism and Democratic Values: Male Vs. Female Preferences

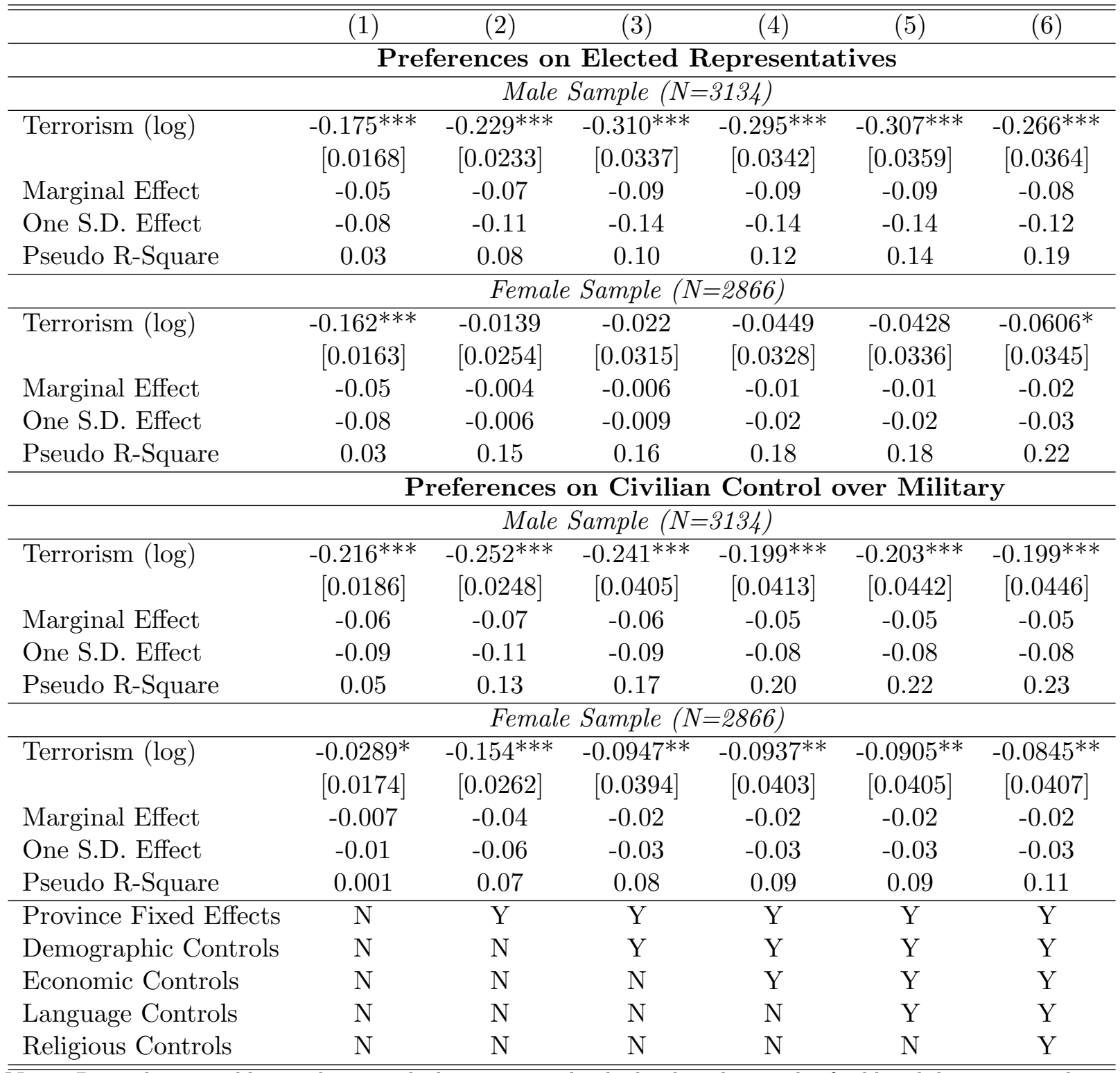

Note: Dependent variable is a dummy which captures individual political attitudes for liberal democratic values. Probit regressions predicting preferences for institutional norms (govern by elected representatives \& civilian control over military). Demographic controls include marital status, rural/urban, age, age-square and formal education level. Economic controls include nominal income, occupation, assets, multiple deprivation index, perceptions on land reforms, inequality, future financial expectations and financial comparison with the neighborhood. Language controls for five main languages speak across Pakistan. Religious controls include sect type, number of prayers, recitation of the holy book, frequency of recitation and current role of the Sharia's law. Robust standard errors (clustered at district level) are presented in brackets.

$* * * p<0.01, * * p<0.05$ and $* p<0.10$. 
mated regression coefficients and corresponding one S.D. effect are approximately similar between rural-urban distribution, when we consider the first measure of liberal democratic norm (elected representatives). Similarly, a one S.D. effect of terrorism is also analogous to the baseline regressions coefficients given in table 4.

An important conclusion can be drawn from the rural-urban classification when we compare democratic preferences on the 'civilian control over military.' One can clearly see in table 8 that the effects of a S.D. increase in terrorism are 3-4 percentage points larger in magnitude than those observed in the baseline table 4, when we consider urban sample. In between comparison, the magnitude of a one S.D. change for urban sample is 8-10 percentage points larger than the rural.

A plausible explanation of significantly larger support for the military institution in urban areas is the consistent threat of terrorism. As mentioned above, urban population is more exposed to terrorism risk than rural residents, therefore, their preferences are relatively skewed towards military institution than parliament to protect their life and property.

\subsubsection{Low, Medium and High Education}

Let us now investigate whether the effect of terrorism on democratic attitudes is heterogeneous by education level. Literature on the relationship between education attainment and support for democratic values has explored positive, both statistically significant and insignificant, effects. Different studies analyzed the impact of education on civic participation, including voting behavior and participation (Acemoglu et al., 2005a; Glaeser et al., 2007; Spilimbergo, 2009), to mention few. Specifically, Lipset (1959) argues that "Education presumably broadens men's outlooks, enables them to understand the need for norms of tolerance, restrains them from adhering to extremist and monistic doctrines, and increases their capacity to make rational electoral choices ..."

Table 9 presents evidence based on three different categories of education. The first category (Edu 1) includes those observations which are either illiterate or completed primary level (five years of education). The estimated values of terrorism variable for both proxies of democratic values are approximately similar to our baseline regression specifications given in table 4 .

The second category (Edu 2) consists of education level above primary (five years) till 10 years of schooling. Again, the results are in line with the baseline specification in signs, significance and magnitudes. 
Table 8: Terrorism and Democratic Values: Rural Vs. Urban Preferences

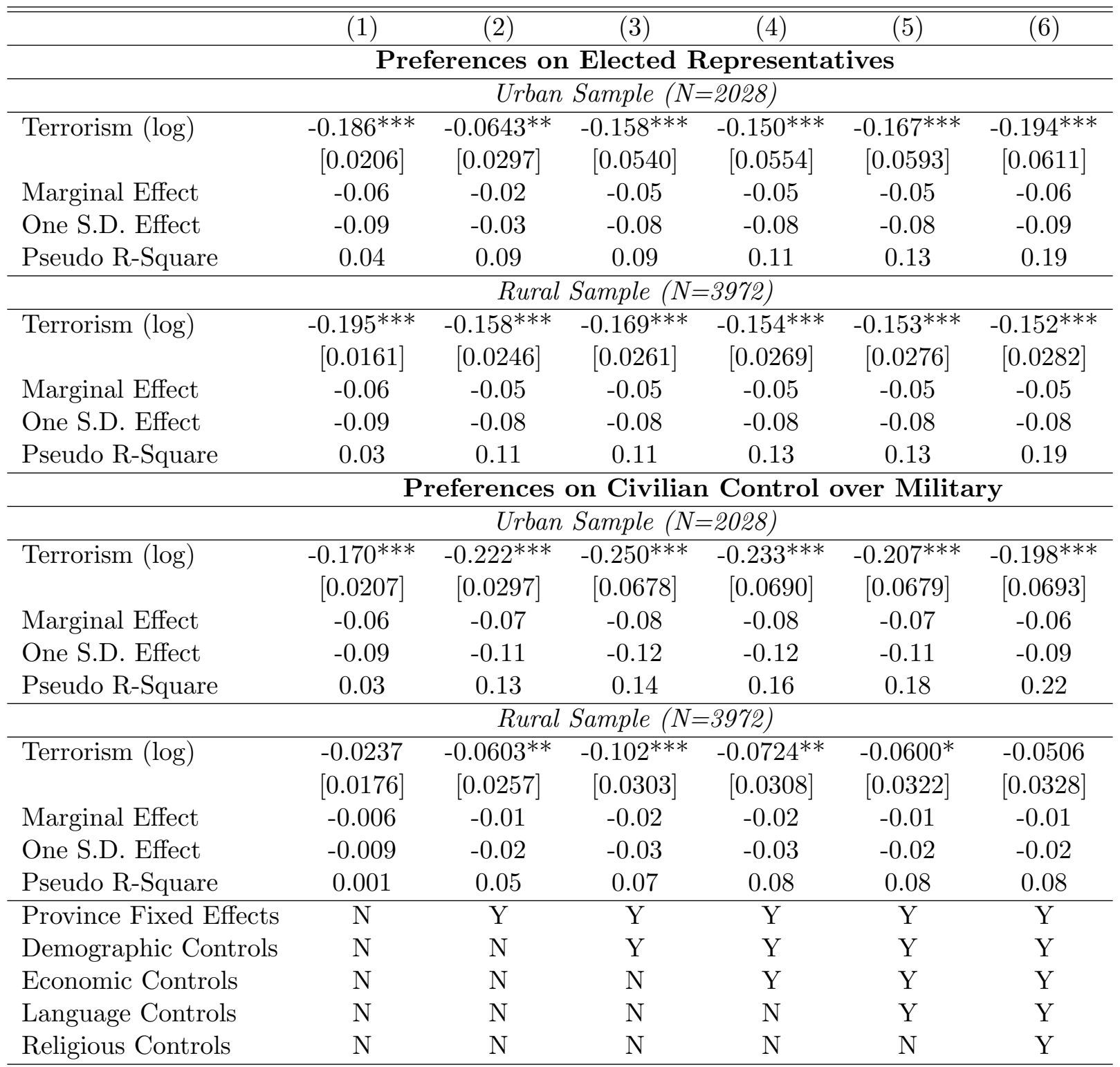

$\overline{\text { Note: Dependent variable is a dummy which captures individual political attitudes for liberal democratic values. }}$ Probit regressions predicting preferences for institutional norms (govern by elected representatives \& civilian control over military). Demographic controls include gender, marital status, age, age-square and formal education level. Economic controls include nominal income, occupation, assets, multiple deprivation index, perceptions on land reforms, inequality, future financial expectations and financial comparison with the neighborhood. Language controls for five main languages speak across Pakistan. Religious controls include sect type, number of prayers, recitation of the holy book, frequency of recitation and current role of the Sharia's law. Robust standard errors (clustered at district level) are presented in brackets.

$* * * p<0.01, * * p<0.05$ and $* p<0.10$. 
Finally, the third group (Edu 3) categorizes individuals whose education level is above 10 years of schooling. Compare with the baseline regressions, the coefficients of terrorism are relatively unstable in signs, significance and absolute values. Two possible reasons may explain this volatile behavior of coefficients. First, the sample size of this category is low compare to the first two, which might affect the precision of the estimates. Second, educated individuals' democratic attitudes may be more deeply rooted and less affected by exposure to terrorism.

Table 9: Terrorism and Democratic Values: Educational Heterogeneity

\begin{tabular}{|c|c|c|c|c|c|c|}
\hline & (1) & $(2)$ & $(3)$ & (4) & (5) & (6) \\
\hline \multicolumn{7}{|c|}{ Preferences on Elected Representatives } \\
\hline \multicolumn{7}{|c|}{ Five Years of Education $(N=2682)$} \\
\hline \multirow[t]{3}{*}{ Terrorism (log) } & $-0.211^{* * *}$ & $-0.105^{* * *}$ & $-0.122^{* * *}$ & $-0.142^{* * *}$ & $-0.139^{* * *}$ & $-0.139^{* * *}$ \\
\hline & {$[0.0192]$} & {$[0.0284]$} & {$[0.0340]$} & {$[0.0355]$} & {$[0.0366]$} & {$[0.0370]$} \\
\hline & \multicolumn{6}{|c|}{ Six-Ten Years of Education $(N=1942)$} \\
\hline \multirow[t]{2}{*}{ Terrorism $(\log )$} & $-0.189^{* * *}$ & $-0.129 * * *$ & $-0.168^{* * *}$ & $-0.157^{* * *}$ & $-0.163^{* * *}$ & $-0.164^{* * *}$ \\
\hline & {$[0.0199]$} & {$[0.0290]$} & {$[0.0377]$} & {$[0.0384]$} & {$[0.0389]$} & {$[0.0397]$} \\
\hline \multicolumn{7}{|c|}{ Above Ten Years of Education $(N=1259)$} \\
\hline \multirow[t]{4}{*}{ Terrorism (log) } & $-0.0965^{* * *}$ & $-0.0710^{*}$ & $-0.121^{* *}$ & $-0.0999^{*}$ & -0.094 & -0.0927 \\
\hline & {$[0.0233]$} & {$[0.0363]$} & {$[0.0586]$} & {$[0.0586]$} & {$[0.0606]$} & {$[0.0619]$} \\
\hline & \multicolumn{6}{|c|}{ Preferences on Civilian Control over Military } \\
\hline & \multicolumn{6}{|c|}{ Five Years of Education ( $N=2682)$} \\
\hline \multirow[t]{2}{*}{ Terrorism $(\log )$} & $-0.0466^{* *}$ & $-0.0918^{* * *}$ & $-0.184^{* * *}$ & $-0.173^{* * *}$ & $-0.160^{* * *}$ & $-0.158^{* * *}$ \\
\hline & {$[0.0202]$} & {$[0.0296]$} & {$[0.0411]$} & {$[0.0421]$} & {$[0.0435]$} & {$[0.0437]$} \\
\hline \multicolumn{7}{|c|}{ Six-Ten Years of Education $(N=1942)$} \\
\hline \multirow[t]{2}{*}{ Terrorism $(\log )$} & $-0.106^{* * *}$ & $-0.202^{* * *}$ & $-0.137^{* * *}$ & $-0.124^{* * *}$ & $-0.126^{* * *}$ & $-0.128^{* * *}$ \\
\hline & {$[0.0214]$} & {$[0.0316]$} & {$[0.0476]$} & {$[0.0478]$} & {$[0.0484]$} & {$[0.0496]$} \\
\hline \multicolumn{7}{|c|}{ Above Ten Years of Education $(N=1259)$} \\
\hline Terrorism $(\log )$ & $-0.246^{* * *}$ & $-0.249^{* * *}$ & $-0.114^{*}$ & -0.0842 & -0.105 & -0.0951 \\
\hline & {$[0.0263]$} & {$[0.0375]$} & [0.0692] & {$[0.0727]$} & [0.0733] & {$[0.0717]$} \\
\hline Province Fixed Effects & $\mathrm{N}$ & $\mathrm{Y}$ & $\mathrm{Y}$ & $\mathrm{Y}$ & $\mathrm{Y}$ & $\mathrm{Y}$ \\
\hline Demographic Controls & $\mathrm{N}$ & $\mathrm{N}$ & Y & Y & $\mathrm{Y}$ & $\mathrm{Y}$ \\
\hline Economic Controls & $\mathrm{N}$ & $\mathrm{N}$ & $\mathrm{N}$ & Y & $\mathrm{Y}$ & $\mathrm{Y}$ \\
\hline Language Controls & $\mathrm{N}$ & $\mathrm{N}$ & $\mathrm{N}$ & $\mathrm{N}$ & Y & $\mathrm{Y}$ \\
\hline Religious Controls & $\mathrm{N}$ & $\mathrm{N}$ & $\mathrm{N}$ & $\mathrm{N}$ & $\mathrm{N}$ & Y \\
\hline
\end{tabular}

Note: Dependent variable is a dummy which captures individual political attitudes for liberal democratic values. Probit regressions predicting preferences for institutional norms (govern by elected representatives \& civilian control over military). Demographic controls include gender, marital status, rural/urban, age and agesquare. Economic controls include nominal income, occupation, assets, multiple deprivation index, perceptions on land reforms, inequality, future financial expectations and financial comparison with the neighborhood. Language controls for five main languages speak across Pakistan. Religious controls include sect type, number of prayers, recitation of the holy book, frequency of recitation and current role of the Sharia's law. Robust standard errors (clustered at district level) are presented in brackets.

$* * * p<0.01, * * p<0.05$ and $* p<0.10$. 


\section{Terrorism, Income and Media Coverage}

In this section we explore two channels through which terrorism may affect democratic attitudes. In particular, we investigate whether the negative effect of terrorism on democratic preferences depends on individual income and on individual access to the media.

\subsection{The Income Channel}

The economic literature has documented that terrorism and civil conflict impose significant economic costs on different sectors of the economy. Terrorism and violence reduce tourism, foreign direct investment, trade, transportation and telecommunication, etc. (Abadie and Gardeazabal, 2003; Chen and Siems, 2004; Frey et al., 2007; Guidolin and La Ferrara, 2007; Sandler and Enders, 2008), to mention few. Some studies have also found a significant positive correlation between economic development and liberal democratic norms. For instance, the positive statistical association between higher income per capita and democracy is the cornerstone of the influential modernization theory (Lipset, 1959). The hypothesis that higher income per capita leads countries to become democratic is also supported by (Rueschemeyer et al., 1992; Huntington, 1993; Barro, 1999). On the basis of these ideas, one might conjecture that terrorism reduces income, and that lower income leads to lower support for democracy. Yet, Acemoglu et al. (2005b) finds that controlling for country fixed effects removes the statistical association between income per capita and various measures of democracy, so the support for the second link in the previous conjecture (from income to democratic values) is at best weak in existing evidence. Nevertheless, it is worth exploring whether terrorism has a differential impact on democratic attitudes at different income levels.

\subsection{The Information Flow Channel}

Social scientists, political economists and defense analysts argue that media exposure in its various forms (electronic and print media, social media and communicative devices like cell phones) plays a significant role in the promotion of terrorist activities (Nacos, 2002; Lewis, 2005; Rohner and Frey, 2007; Seib and Janbek, 2010; Hoffman, 2013, among others). For instance, Hoffman (2013) argues that, "without the media's coverage, the act's impact is arguably wasted, remaining narrowly confined to the immediate victim(s) of the attack, rather than reaching the wider 'target audience' at 
whom the terrorists' violence is actually aimed." Correspondingly, research revealed a significant positive relationship between the use of media and political mobilization and information transmission, particularly during election campaigns (Berelson, 1954; Drew and Weaver, 1998; Tolbert and McNeal, 2003; Eveland Jr et al., 2005; Dalrymple and Scheufele, 2007). For this analysis, media exposure means that an individual has an access to at least one of the sources of information flow including TV, radio, newspaper (print and electronic), internet (social media) and cell phone.

\subsection{The Empirics}

Table 10 presents democratic attitudes regressions, in which media exposure, and the interaction of terrorism with income and media exposure, are progressively added to the specification of table 4, column (6). Moreover, the coefficient of individual income, which was already included in baseline estimates, is now highlighted. We find that terrorism affects support for elected governments in a similar way for the rich and the poor, but it affects support for civilian control over the military more strongly among the poor than among the rich. This result appears in line with the findings obtained by splitting the sample by education level. We also find that the negative impact of terrorism on democratic attitudes is more pronounced among individuals with media exposure than among individuals without access to media news. This suggests that part of the effect indeed works through information transmission over the media.

\section{An Instrumental Variable Approach}

\subsection{Instruments}

In our baseline regressions we control for several demographic, socio-economic and religious characteristics at both individual and district level. In particular, we include factors that might influence both democratic attitudes and the number of terrorist events, in order to minimize the likelihood of spurious correlation. Similarly, we separate samples on the basis of gender, urbanization and education level to assess heterogeneous effects. We also argue that district level terrorist attacks are likely to be exogenous to individual level political preferences.

A potential threat to exogeneity would come from the possibility that terrorists, being democ-

racy averse, disproportionately target districts with higher liberal norms. Per se, this would lead 
Table 10: Income, Media Exposure and Democratic Values

\begin{tabular}{|c|c|c|c|c|}
\hline & (1) & $(2)$ & $(3)$ & $(4)$ \\
\hline & \multicolumn{4}{|c|}{ Preferences on Elected Representatives } \\
\hline \multirow[t]{2}{*}{ Nominal Income } & $0.0236^{* * *}$ & $0.0348^{* * *}$ & $0.0239 * * *$ & $0.0365^{* * *}$ \\
\hline & {$[0.00610]$} & {$[0.0118]$} & {$[0.00607]$} & {$[0.0119]$} \\
\hline \multirow[t]{2}{*}{ Media Exposure } & $0.213^{* * *}$ & $0.214^{* * *}$ & $0.438^{* * *}$ & $0.448^{* * *}$ \\
\hline & {$[0.0691]$} & {$[0.0692]$} & {$[0.126]$} & {$[0.127]$} \\
\hline \multirow[t]{2}{*}{ Terrorism (Log) } & $-0.148^{* * *}$ & $-0.112^{* * *}$ & $-0.104^{* * *}$ & -0.0617 \\
\hline & {$[0.0319]$} & {$[0.0430]$} & {$[0.0348]$} & {$[0.0463]$} \\
\hline \multirow[t]{2}{*}{ Nominal Income*Terrorism (Log) } & & -0.00387 & & -0.00434 \\
\hline & & {$[0.00322]$} & & {$[0.00321]$} \\
\hline \multirow[t]{2}{*}{ Media Exposure*Terrorism (Log) } & & & $-0.0848 * *$ & $-0.0881^{* *}$ \\
\hline & & & {$[0.0357]$} & {$[0.0359]$} \\
\hline \multirow[t]{2}{*}{ R-Square } & 0.13 & 0.13 & 0.13 & 0.13 \\
\hline & Preferenc & es on Civili & n Control & er Military \\
\hline \multirow[t]{2}{*}{ Nominal Income } & $0.0204^{* * *}$ & 0.00504 & $0.0217 * * *$ & 0.00888 \\
\hline & {$[0.00450]$} & {$[0.00716]$} & {$[0.00453]$} & {$[0.00739]$} \\
\hline \multirow[t]{2}{*}{ Media Exposure } & $0.460 * * *$ & $0.454^{* * *}$ & $1.019 * * *$ & $0.998 * * *$ \\
\hline & {$[0.0618]$} & {$[0.0620]$} & {$[0.107]$} & {$[0.108]$} \\
\hline \multirow[t]{2}{*}{ Terrorism (Log) } & $-0.105^{* * *}$ & $-0.109^{* * *}$ & $-0.0931^{* * *}$ & 0.0328 \\
\hline & {$[0.0350]$} & {$[0.0387]$} & {$[0.0352]$} & {$[0.0439]$} \\
\hline \multirow[t]{2}{*}{ Nominal Income*Terrorism (Log) } & & $0.00657^{* * *}$ & & $0.00545^{* *}$ \\
\hline & & {$[0.00242]$} & & {$[0.00242]$} \\
\hline \multirow[t]{2}{*}{ Media Exposure*Terrorism (Log) } & & & $-0.229 * * *$ & $-0.223^{* * *}$ \\
\hline & & & {$[0.0328]$} & {$[0.0330]$} \\
\hline R-Square & 0.16 & 0.17 & 0.17 & 0.17 \\
\hline Province Fixed Effects & $\mathrm{Y}$ & $\mathrm{Y}$ & $\mathrm{Y}$ & $\mathrm{Y}$ \\
\hline Demographic Controls & $\mathrm{Y}$ & $\mathrm{Y}$ & $\mathrm{Y}$ & $\mathrm{Y}$ \\
\hline Language Controls & $\mathrm{Y}$ & $\mathrm{Y}$ & $\mathrm{Y}$ & $\mathrm{Y}$ \\
\hline Religious Controls & $\mathrm{Y}$ & $\mathrm{Y}$ & $\mathrm{Y}$ & $\mathrm{Y}$ \\
\hline \multicolumn{5}{|c|}{$\begin{array}{l}\text { Jote: Dependent variable is a dummy which captures individual political attitudes for liberal } \\
\text { emocratic values. Probit regressions predicting preferences for institutional norms (govern by } \\
\text { lected representatives }(\mathrm{N}=4071) \text { \& civilian control over military }(\mathrm{N}=4035) \text { ). Demographic controls } \\
\text { aclude gender, marital status, rural/urban, age and age-square. Language controls for five main } \\
\text { anguages speak across Pakistan. Religious controls include sect type, number of prayers, recitation } \\
\text { f the holy book, frequency of recitation and current role of the Sharia's law. Robust standard errors } \\
\text { clustered at district level) are presented in brackets. } \\
* * p<0.01, * * p<0.05 \text { and } * p<0.10 \text {. }\end{array}$} \\
\hline
\end{tabular}


to a positive estimated coefficient of terrorism, whereas we find it to be negative. If attacks are partly caused by democratic values, then our findings provide a lower bound (in absolute value) for the true effect of terrorism on democratic attitudes. At any rate, since it is possible to question the exogeneity of terrorism, also on the grounds of omitted variables and measurement error, we utilize an instrumental variable identification strategy.

We use distance of a district from the Durand Line as an instrument as we believe that most of the terrorist organizations have safe havens in the impervious mountainous terrain of the PakAfghan border due to high cost of state policing (Jones and Fair, 2010; Johnston and Sarbahi, 2013). Intuitively, districts closer to the Pak-Afghan border are easy targets for terrorists as compared to distant districts (see figure 5). The identifying assumption is that the variable of distance affects only the distribution of terrorism, and does not have an impact on democratic preferences. If this assumption is considered further, we can argue that distance from the Durand Line can affect political preferences through socio-economic and religious heterogeneity across districts. However, there are variations within a province irrespective of the distance from the Durand Line. All the provinces and districts are governed by the same laws, have Muslim majority population and speak different languages, irrespective of any distance variable. Yet, we still control our first stage regression with the provincial fixed effects.

We also use religious fractionalization as an instrument when we analyze the correlation between violent conflicts (alternative to terrorist attacks) and support for democratic values. There exists a large number of religious Muslim sects and subsects in Pakistan, due to different interpretations of the Sharia. It is argued that in districts with more religious fractionalization, there is a higher probability of religious and communal conflict (Esteban and Ray, 2008, 2011; Esteban and Mayoral, 2011; Esteban et al., 2012). Similarly, this instrument can be excluded from the second stage regression, since different interpretations of the Sharia law do not explicitly discuss modern political and democratic processes. Hence, we believe that sect affiliation does not directly affect political and democratic preferences other than through violent conflicts. We construct the HerfindahlHirschman Index (HHI) of religious concentration based on district level different religious sects and subsects within Islam. The summary statistics of HHI is given in table 3 . 


\subsection{Regression Results}

Table 11 reports IV regression results, using the same specifications of table 4 for included controls. The first stage regression provides evidence of a statistically significant negative association between distance from the Durand Line and frequency of terrorist attacks. The second stage coefficient of terrorism is similar in sign and significance, except in specification (1), to the one found in our baseline regressions, although it now tends to be higher in magnitude than in table 4. A one S.D. change in terrorist attacks decreases support for elected governments by $5-11 \%$, and raises support for the military by $8-11 \%$.

A similar IV exercise is repeated to analyze the impact of aggregate violent conflicts on democratic attitudes, and the results are presented in table 12. The first stage regression validates religious fractionalization as a major determinant of violence in Pakistan. The estimated coefficient of violence in the second stage has the same sign, magnitude and significance as in the baseline regressions in table 5. A one S.D. increase in the aggregate violence lowers support for elected governments by $4-11 \%$, and raises support for the military by $6-7 \%$.

\section{Conclusion}

Terrorism and violence produce not only direct damages, but also a modification of individual attitudes in a number of domains, including risk, altruism and impatience (Voors et al., 2012). In this paper, we investigate the institutional legacy of persistent exposure to terrorism by studying its impact on individual attitudes towards democracy. We exploit information on political attitudes from a micro survey conducted on 6,000 respondents in Pakistan in 2009, together with district level information on exposure to terrorism between 2004 and 2008. We find that, controlling for a number of individual and district characteristics, persistent exposure to terrorism is associated to a significantly lower support for democratic values. A one-standard-deviation increase in terrorist attacks in a district is associated to an individual support for elected legislators that is lower

by $7-9 \%$ (depending on the specification). Very similar results hold for district level exposure to violence (more broadly defined) and for individual support for civilian control over the military. These results are robust to the inclusion of different sets of control variables, as well as to different sample splits based on gender, urbanization and education level. This attenuates omitted variable 
Table 11: Terrorism and Democratic Values: IV Estimations

\begin{tabular}{lcccccc}
\hline \hline & $(1)$ & $(2)$ & $(3)$ & $(4)$ & $(5)$ & $(6)$ \\
\hline First Stage Instrument & & & & & & \\
Distance from the Durand Line (log) & $-0.531^{* * *}$ & $-0.373^{* * *}$ & $-0.318^{* * *}$ & $-0.316^{* * *}$ & $-0.400^{* * *}$ & $-0.419^{* * *}$ \\
& {$[0.0433]$} & {$[0.0670]$} & {$[0.0659]$} & {$[0.0649]$} & {$[0.0585]$} & {$[0.0579]$} \\
Wald test (p-value) & 0.0001 & 0.741 & 0.071 & 0.111 & 0.011 & 0.003 \\
F test & 37.68 & 30.99 & 23.62 & 23.99 & 47.30 & 51.48 \\
\hline & \multicolumn{7}{c}{ Preferences on Elected Representatives } & \\
\hline Terrorism (log) & 0.00831 & $-0.118^{* * *}$ & $-0.207^{* * *}$ & $-0.196^{* * *}$ & $-0.229^{* * *}$ & $-0.238^{* * *}$ \\
& {$[0.0174]$} & {$[0.0215]$} & {$[0.0382]$} & {$[0.0393]$} & {$[0.0396]$} & {$[0.0406]$} \\
Marginal Effect & 0.003 & -0.03 & -0.06 & -0.06 & -0.07 & -0.06 \\
One S.D. Effect & 0.005 & -0.05 & -0.09 & -0.09 & -0.11 & -0.09 \\
\hline & Preferences on Civilian Control over Military & \\
\hline Terrorism (log) & $-0.233^{* * *}$ & $-0.247^{* * *}$ & $-0.260^{* * *}$ & $-0.238^{* * *}$ & $-0.196^{* * *}$ & $-0.211^{* * *}$ \\
& {$[0.0181]$} & {$[0.0209]$} & {$[0.0442]$} & {$[0.0448]$} & {$[0.0446]$} & {$[0.0448]$} \\
Marginal Effect & -0.06 & -0.06 & -0.07 & -0.06 & -0.05 & -0.05 \\
One S.D. Effect & -0.09 & -0.09 & -0.11 & -0.09 & -0.08 & -0.08 \\
\hline \hline
\end{tabular}

$\overline{\text { Note: Dependent variable is a dummy which captures individual political attitudes for liberal democratic values. IVProbit regressions }}$ predicting preferences for institutional norms (govern by elected representatives $(\mathrm{N}=5891)$ \& civilian control over military $(\mathrm{N}=5770)$ ). Demographic controls include gender, marital status, rural/urban, age, age-square and formal education level. Economic controls include nominal income, occupation, assets, multiple deprivation index, perceptions on land reforms, inequality, future financial expectations and financial comparison with the neighborhood. Language controls for five main languages speak across Pakistan. Religious controls include sect type, number of prayers, recitation of the holy book, frequency of recitation and current role of the Sharia's law. Robust standard errors (clustered at district level) are presented in brackets.

$* * * p<0.01, * * p<0.05$ and $* p<0.10$. 
Table 12: Violence and Democratic Values: IV Estimations

\begin{tabular}{lcccccc}
\hline \hline & $(1)$ & $(2)$ & $(3)$ & $(4)$ & $(5)$ & $(6)$ \\
\hline First Stage Instrument & \multicolumn{7}{c}{. } & & & & \\
HHI of Religious Fractionalization & $0.363^{* * *}$ & $0.902^{* * *}$ & $0.809^{* * *}$ & $0.702^{* * *}$ & $0.291^{* * *}$ & $0.280^{* * *}$ \\
& {$[0.0471]$} & {$[0.0711]$} & {$[0.0726]$} & {$[0.0733]$} & {$[0.0706]$} & {$[0.0704]$} \\
Wald test (p-value) & 0.26 & 0.16 & 0.66 & 0.76 & 0.09 & 0.02 \\
F test & 59.06 & 158.77 & 125.14 & 91.69 & 18.30 & 16.62 \\
\hline & \multicolumn{7}{c}{ Preferences on Elected Representatives } & \\
\hline Violence (log) & 0.0212 & $-0.116^{* * *}$ & $-0.223^{* * *}$ & $-0.216^{* * *}$ & $-0.274^{* * *}$ & $-0.278^{* * *}$ \\
& {$[0.0154]$} & {$[0.0216]$} & {$[0.0449]$} & {$[0.0467]$} & {$[0.0487]$} & {$[0.0505]$} \\
Marginal Effect & 0.007 & -0.03 & -0.06 & -0.06 & -0.08 & -0.08 \\
One S.D. Effect & 0.01 & -0.04 & -0.08 & -0.08 & -0.11 & -0.11 \\
\hline & Preferences on Civilian Control over Military & \\
\hline Violence (log) & $-0.224^{* * *}$ & $-0.231^{* * *}$ & $-0.255^{* * *}$ & $-0.237^{* * *}$ & $-0.245^{* * *}$ & $-0.270^{* * *}$ \\
& {$[0.0141]$} & {$[0.0205]$} & {$[0.0502]$} & {$[0.0521]$} & {$[0.0534]$} & {$[0.0539]$} \\
Marginal Effect & -0.06 & -0.06 & -0.07 & -0.06 & -0.06 & -0.07 \\
One S.D. Effect & -0.08 & -0.08 & -0.10 & -0.08 & -0.08 & -0.10 \\
\hline
\end{tabular}

Note: Dependent variable is a dummy which captures individual political attitudes for liberal democratic values. IVProbit regressions predicting preferences for institutional norms (govern by elected representatives $(\mathrm{N}=5891)$ \& civilian control over military $(\mathrm{N}=5770)$ ). Demographic controls include gender, marital status, rural/urban, age, age-square and formal education level. Economic controls include nominal income, occupation, assets, multiple deprivation index, perceptions on land reforms, inequality, future financial expectations and financial comparison with the neighborhood. Language controls for five main languages speak across Pakistan. Religious controls include sect type, number of prayers, recitation of the holy book, frequency of recitation and current role of the Sharia's law. Robust standard errors (clustered at district level) are presented in brackets. $* * * p<0.01, * * p<0.05$ and $* p<0.10$. 
concerns.

We further argue that the correlation we document is likely to reflect a causal impact of terrorism exposure on political preferences. First, our measure of exposure to terrorism is predetermined relative to the measure of political attitudes. This attenuates endogeneity concerns, but per se it is not enough to rule out reverse causation, which might drive the results if political preferences are persistent and affect the choice of terrorists' targets. Yet, if terrorists attack more frequently more democratically oriented districts, for instance with the aim of undermining democratic systems whose outcomes they do not like, one should expect a positive correlation, so that our results would be reinforced. More troublesome for the causal interpretation of our findings would be the possibility that terrorists preferentially target less democratic districts. To deal with this possibility, as well as with other possible sources of endogeneity, we consider an instrumental variable strategy based on instrumenting terrorism and violence by the distance from the Pak-Afghan border and by religious fractionalization. Such analysis confirms our baseline results, suggesting that persistent exposure to terrorism and violence reduces support for democracy and thus has a negative institutional legacy in terms of a country's chances to keep a democratic system. To the extent that results from Pakistan can be applied to non-democratic countries threatened by terrorism, one might conclude that exposure to terrorism also reduces the chances of a transition to democracy.

In the words of Voors et al. (2012), "while exposure to violence encourages risk-taking and increases the weight people attach to their fellow community members' welfare, arguably positive features for development (at least within certain bounds), it also seems to trigger impatience." Our contribution highlights the institutional legacy of persistent exposure to terrorism and violence by showing that they decrease support for democratic institutions. An interesting avenue of future research is to investigate how these different effects interact with one another and shape a country's economic and institutional response to terrorism.

\section{References}

Abadie, A. and J. Gardeazabal (2003). The Economic Costs of Conflict: A Case Study of the Basque Country. American Economic Review, 113-132.

Acemoglu, D., S. Johnson, J. A. Robinson, and P. Yared (2005a). From Education to Democracy? Technical report, National Bureau of Economic Research. 
Acemoglu, D., S. Johnson, J. A. Robinson, and P. Yared (2005b). Income and Democracy. Technical report, National Bureau of Economic Research.

Acemoglu, D. and J. A. Robinson (2001). A Theory of Political Transitions. American Economic Review, 938-963.

Barro, R. J. (1999). Determinants of Democracy. Journal of Political Economy 107(S6), S158-S183.

Bateson, R. (2012). Crime Victimization and Political Participation. American Political Science Review 106(03), 570-587.

Bellows, J. and E. Miguel (2006). War and Institutions: New Evidence from Sierra Leone. The American Economic Review, 394-399.

Bellows, J. and E. Miguel (2009). War and Local Collective Action in Sierra Leone. Journal of Public Economics 93(11), 1144-1157.

Berelson, B. (1954). Voting: A Study of Opinion Formation in a Presidential Campaign. University of Chicago Press.

Blair, G., C. Christine Fair, N. Malhotra, and J. N. Shapiro (2013). Poverty and Support for Militant Politics: Evidence from Pakistan. American Journal of Political Science 57(1), 30-48.

Blanco, L. (2012). The Impact of Insecurity on Democracy and Trust in Institutions in Mexico. RAND Working Paper.

Blanco, L. and I. Ruiz (2013). The Impact of Crime and Insecurity on Trust in Democracy and Institutions. The American Economic Review 103(3), 284-288.

Blattman, C. (2009). From Violence to Voting: War and Political Participation in Uganda. American Political Science Review 103(02), 231-247.

Brakman, S., H. Garretsen, and M. Schramm (2004). The Strategic Bombing of German Cities During World War II and its Impact on City Growth. Journal of Economic Geography 4(2), 201-218.

Bratton, M. (2008). Vote Buying and Violence in Nigerian Election Campaigns. Electoral Studies $27(4), 621-632$.

Brückner, M. and A. Ciccone (2011). Rain and the Democratic Window of Opportunity. Econometrica $79(3), 923-947$.

Chen, A. H. and T. F. Siems (2004). The Effects of Terrorism on Global Capital Markets. European Journal of Political Economy 20(2), 349-366.

Colletta, N. J. and M. L. Cullen (2000). The Nexus Between Violent Conflict, Social Capital and Social Cohesion: Case Studies from Cambodia and Rwanda. World Bank, Social Development Family, Environmentally and Socially Sustainable Development Network.

Collier, P. (2007). The Bottom Billion. Oxford University Press.

Collier, P. and Others (2003). Breaking the Conflict Trap: Civil War and Development Policy. World Bank Publications. 
Collier, P. and P. C. Vicente (2014). Votes and Violence: Evidence from a Field Experiment in Nigeria. The Economic Journal 124(574), F327-F355.

Cramer, C. (2006). Civil War is Not a Stupid Thing: Accounting for Violence in Developing Countries. Hurst \& Company.

Dalrymple, K. E. and D. A. Scheufele (2007). Finally Informing the Electorate? How the Internet Got people Thinking about Presidential Politics in 2004. The Harvard International Journal of Press/Politics 12(3), 96-111.

Davis, D. R. and D. E. Weinstein (2002). Bones, Bombs and Break Points: The Geography of Economic Activity. American Economic Review 92(5), 1269-1289.

De Mesquita, E. B., C. C. Fair, R. B. Rais, and J. N. Shapiro (2013). Empirical Studies of Conflict (ESOC) [Data file]. Technical report, https://esoc.princeton.edu/files/bfrs-political-violencepakistan-dataset.

Drew, D. and D. Weaver (1998). Voter Learning in the 1996 Presidential Election: Did the Media Matter? Journalism \&3 Mass Communication Quarterly 75(2), 292-301.

Economic Survey (2013). Pakistan Economic Survey. Technical report, Ministry of Finance: http://finance.gov.pk/survey/chapters_14/Annex_3.pdf.

Esteban, J. and L. Mayoral (2011). Ethnic and Religious Polarization and Social Conflict.

Esteban, J., L. Mayoral, and D. Ray (2012). Ethnicity and Conflict: An Empirical Study. The American Economic Review 102(4), 1310-1342.

Esteban, J. and D. Ray (2008). Polarization, Fractionalization and Conflict. Journal of Peace Research 45(2), 163-182.

Esteban, J. and D. Ray (2011). Linking Conflict to Inequality and Polarization. The American Economic Review 101(4), 1345-1374.

Eveland Jr, W. P., A. F. Hayes, D. V. Shah, and N. Kwak (2005). Understanding the Relationship between Communication and Political Knowledge: A Model Comparison Approach Using Panel Data. Political Communication 22(4), 423-446.

Fair, C. C., N. Malhotra, and J. N. Shapiro (2013). Democratic Values and Support for Militant Politics: Evidence from a National Survey of Pakistan. Journal of Conflict Resolution.

Freedom House (2011). Freedom in the World 2011. Technical report, Washington, DC: Freedom House. http://freedomhouse.org/report/freedom-press/freedom-press-2011.

Freedom House (2014). Freedom in the World 2014 @Online: https://freedomhouse.org/report/freedom-world/2014/pakistan.

Frey, B. S., S. Luechinger, and A. Stutzer (2007). Calculating Tragedy: Assessing the Costs of Terrorism. Journal of Economic Surveys 21(1), 1-24.

Gilligan, M., B. J. Pasquale, and C. D. Samii (2010). Civil War and Social Capital: BehavioralGame Evidence from Nepal. Unpublished Manuscript, Columbia University. 
Glaeser, E. L., G. A. Ponzetto, and A. Shleifer (2007). Why Does Democracy Need Education? Journal of Economic Growth 12(2), 77-99.

Global Terrorism Database (2013). National Consortium for the Study of Terrorism and Responses to Terrorism (START) [Data File]. Technical report, Retrieved from http://www.start.umd.edu/gtd.

Guidolin, M. and E. La Ferrara (2007). Diamonds Are Forever, Wars Are Not: Is Conflict Bad for Private Firms? The American Economic Review, 1978-1993.

Hillman, A. L. (2010). Expressive Behavior in Economics and Politics. European Journal of Political Economy 26(4), 403-418.

Hoffman, B. (2013). Inside terrorism. Columbia University Press.

Huntington, S. P. (1993). The Third Wave: Democratization in the Late Twentieth Century, Volume 4. University of Oklahoma press.

ICG (2013). Parliament's Role in Pakistan's Democratic Transition. Technical report, International Crisis Group.

Johnston, P. and A. Sarbahi (2013). The Impact of US Drone Strikes on Terrorism in Pakistan and Afghanistan. New America Foundation.

Jones, S. G. and C. C. Fair (2010). Counterinsurgency in Pakistan. Technical report, DTIC Document.

Lewis, J. (2005). Language Wars: The Role of Media and Culture in Global Terror and Political Violence. Pluto Press.

Lipset, S. M. (1959). Some Social Requisites of Democracy: Economic Development and Political Legitimacy. American Political Science Review 53(1), 69-105.

Miguel, E. and G. Roland (2011). The Long-Run Impact of Bombing Vietnam. Journal of Development Economics 96(1), 1-15.

Munck, G. L. and J. Verkuilen (2002). Conceptualizing and Measuring Democracy Evaluating Alternative Indices. Comparative Political Studies 35(1), 5-34.

Nacos, B. (2002). Terrorism, the Mass Media, and the Events of 9-11. In Phi Kappa Phi Forum, Volume 82, pp. 13. National Forum: Phi Kappa Phi Journal.

Pinchotti, S. and P. Verwimp (2007). Social Capital and the Rwandan Genocide: A Micro-Level Analysis. Technical report, Households in Conflict Network.

Ramsay, K. W. (2011). Revisiting the Resource Curse: Natural Disasters, the Price of Oil and Democracy. International Organization 65(03), 507-529.

Rohner, D. and B. S. Frey (2007). Blood and Ink! The Common-Interest-Game between Terrorists and the Media. Public Choice 133(1-2), 129-145.

Rueschemeyer, D., E. H. Stephens, and J. D. Stephens (1992). Capitalist Development and Democracy. Cambridge, UK. 
Sandler, T. and W. Enders (2008). Economic Consequences of Terrorism in Developed and Developing Countries. Terrorism, Economic Development, and Political Openness $1 \%$.

Seib, P. and D. M. Janbek (2010). Global Terrorism and New Media: The Post-Al-Qaeda Generation. Routledge.

Spilimbergo, A. (2009). Democracy and Foreign Education. The American Economic Review, $528-543$.

Tedeschi, R. G. and L. G. Calhoun (2004). Posttraumatic Growth: Conceptual Foundations and Empirical Evidence. Psychological Inquiry 15(1), 1-18.

Tolbert, C. J. and R. S. McNeal (2003). Unraveling the Effects of the Internet on Political Participation? Political Research Quarterly 56(2), 175-185.

Tshangana, A. H. (2010). Constituency Development Funds: Scoping Paper. Cell 83(280), 2759.

Voors, M. J., E. E. Nillesen, P. Verwimp, E. H. Bulte, R. Lensink, and D. P. Van Soest (2012). Violent Conflict and Behavior: A Field Experiment in Burundi. The American Economic Review 102(2), 941-964.

WDI (2015). World Development Indicators (WDI) @Online: http://data.worldbank.org/indicator/SL.TLF.CACT.FE.ZS.

Wood, E. J. (2003). Insurgent Collective Action and Civil War in El Salvador. Cambridge University Press. 


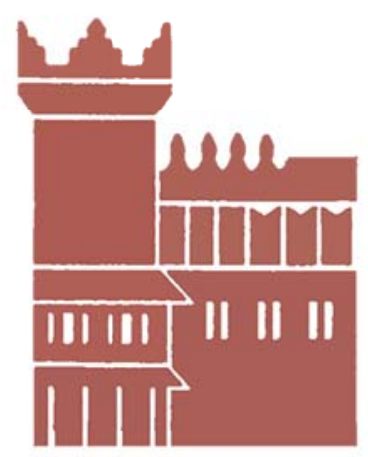

Alma Mater Studiorum - Università di Bologna DEPARTMENT OF ECONOMICS

Strada Maggiore 45

40125 Bologna - Italy

Tel. +39051 2092604

Fax +390512092664

http://www.dse.unibo.it 